\title{
Review \\ Role of Creatine Supplementation in Conditions Involving Mitochondrial Dysfunction: A Narrative Review
}

\author{
Robert Percy Marshall ${ }^{1, *(\mathbb{D})}$, Jan-Niklas Droste ${ }^{1}$, Jürgen Giessing ${ }^{2}$ and Richard B. Kreider ${ }^{3}$ (i) \\ 1 Medical Department, RasenBallsport Leipzig GmbH, 04177 Leipzig, Germany; jan-niklas.droste@redbulls.com \\ 2 Faculty of Natural and Environmental Sciences, Institute of Sports Science, Universität Koblenz-Landau, \\ 76829 Landau, Germany; giessing@uni-landau.de \\ 3 Exercise \& Sport Nutrition Lab, Human Clinical Research Facility, Department of Health \& Kinesiology, Texas \\ A\&M University, College Station, TX 77843, USA; rbkreider@tamu.edu \\ * Correspondence: Robert.Marshall@redbulls.com
}

check for updates

Citation: Marshall, R.P.; Droste, J.-N.; Giessing, J.; Kreider, R.B. Role of Creatine Supplementation in Conditions Involving Mitochondrial Dysfunction: A Narrative Review. Nutrients 2022, 14, 529. https:// doi.org/10.3390/nu14030529

Academic Editor: Theo Wallimann

Received: 14 December 2021

Accepted: 24 January 2022

Published: 26 January 2022

Publisher's Note: MDPI stays neutral with regard to jurisdictional claims in published maps and institutional affiliations.

Copyright: (C) 2022 by the authors. Licensee MDPI, Basel, Switzerland. This article is an open access article distributed under the terms and conditions of the Creative Commons Attribution (CC BY) license (https:// creativecommons.org/licenses/by/ $4.0 /)$.

\begin{abstract}
Creatine monohydrate ( $\mathrm{CrM})$ is one of the most widely used nutritional supplements among active individuals and athletes to improve high-intensity exercise performance and training adaptations. However, research suggests that CrM supplementation may also serve as a therapeutic tool in the management of some chronic and traumatic diseases. Creatine supplementation has been reported to improve high-energy phosphate availability as well as have antioxidative, neuroprotective, anti-lactatic, and calcium-homoeostatic effects. These characteristics may have a direct impact on mitochondrion's survival and health particularly during stressful conditions such as ischemia and injury. This narrative review discusses current scientific evidence for use or supplemental CrM as a therapeutic agent during conditions associated with mitochondrial dysfunction. Based on this analysis, it appears that CrM supplementation may have a role in improving cellular bioenergetics in several mitochondrial dysfunction-related diseases, ischemic conditions, and injury pathology and thereby could provide therapeutic benefit in the management of these conditions. However, larger clinical trials are needed to explore these potential therapeutic applications before definitive conclusions can be drawn.
\end{abstract}

Keywords: mitochondriopathia; cardiac infarction; chronic fatigue syndrome; long COVID; ischemia; hypoxia; stroke; neurodegenerative diseases; oxidative stress; noncommunicable disease

\section{Introduction}

Creatine ( $\mathrm{N}$-aminoiminomethyl- $\mathrm{N}$-methyl glycine) is a naturally occurring and nitrogen containing compound synthesized from the amino acids glycine, methionine that is classified within the family of guanidine phosphagens [1,2]. About one half the daily need for creatine is obtained from endogenous synthesis while the remaining is obtained from the diet, primarily red meat, fish, or dietary supplements $[3,4]$. Creatine is mainly stored in the muscle (95\%) with the remaining found in the heart, brain, and testes [3-6], with about $2 / 3$ in the form of $\mathrm{PCr}$ and the remaining as free creatine $[4,5,7]$. The metabolic basis of creatine in health and disease has been recently reviewed in detail by Bonilla and colleagues [1] (see Figure 1). Briefly, adenosine triphosphate (ATP) serves as the primary source of energy in most living cells. Enzymatic degradation of ATP into adenosine diphosphate (ADP) and inorganic phosphate $(\mathrm{Pi})$ liberates free energy to fuel metabolic activity. However, only a small amount of ATP is stored in the cell. Energy derived from the degradation of phosphocreatine (PCr) serves to resynthesize ADP and Pi back to ATP to maintain cellular function until glycolysis in the cytosol and oxidative phosphorylation in the mitochondria can produce enough ATP to meet metabolic demands. Creatine also plays an important role in shuttling Pi from the mitochondria into the cytosol to form PCr to help maintain cellular bioenergetics (i.e., Creatine Phosphate Shuttle) [8]. In this way, $\mathrm{PCr}$ can donate its phosphate to ADP, thereby restoring ATP for cellular needs leaving creatine in the cytosol 
to diffuse back into the mitochondria to shuttle the next phosphate to locations far from its production site [8]. The ATP stored in the cells is usually sufficient for energy depletion that lasts less than two seconds. However, another two to seven seconds of muscle contractions are fueled by depleting available PCr stores [9]. Together, the ATP-PCr energy system provides energy to fuel short-term explosive exercise. Increasing $\mathrm{PCr}$ and creatine in muscle provides an energy reserve to meet anaerobic energy needs, thereby providing a critical source of energy particularly during ischemia, injury, and/or in response to impaired mitochondrial function $[8,10]$.

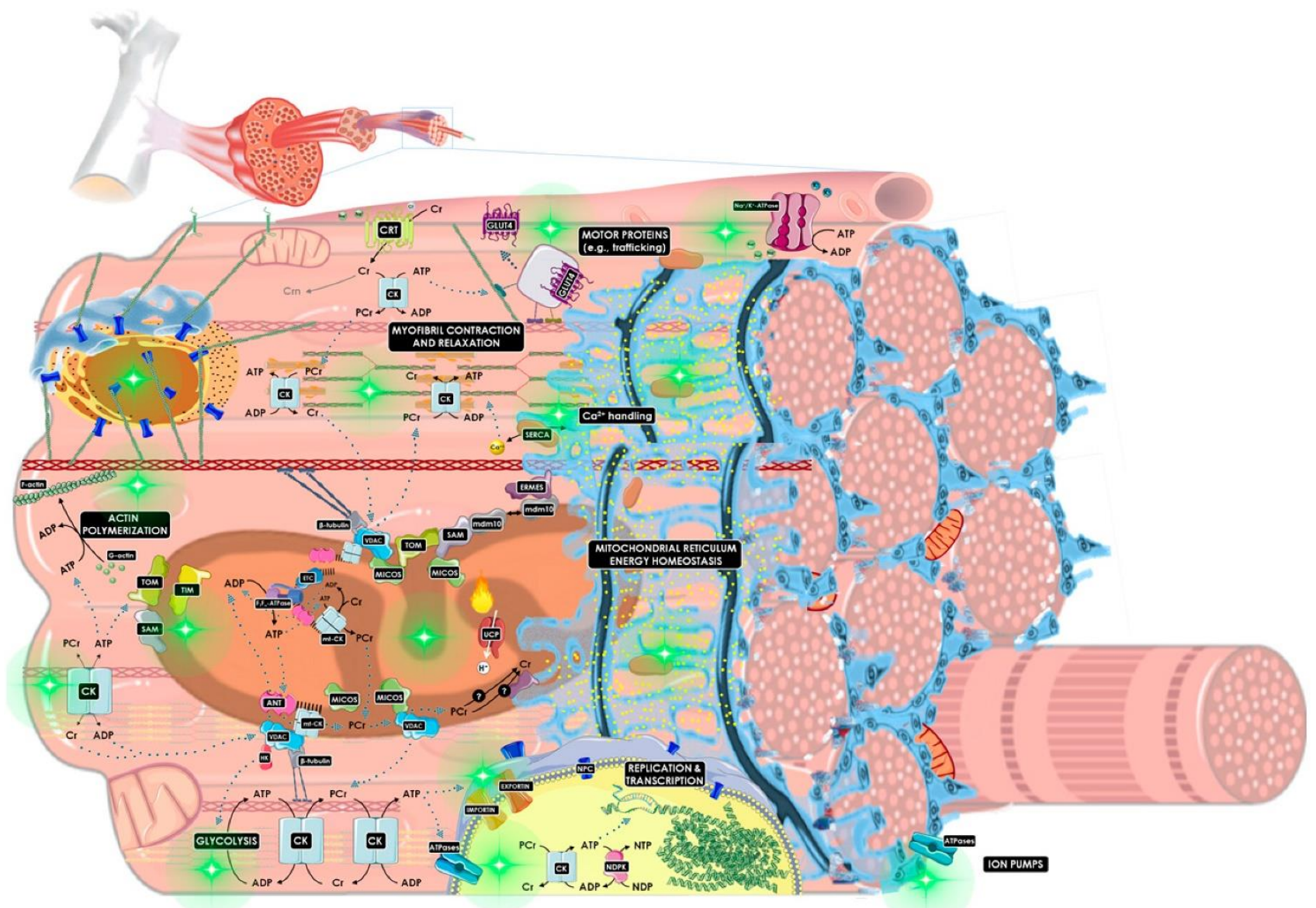

Figure 1. General overview of the metabolic role of creatine in the creatine kinase/phosphocreatine (CK/PCr) system [1]. The diagram depicts connected subcellular energy production and cellular mechanics of creatine metabolism. This chemo-mechanical energy transduction network involves structural and functional coupling of the mitochondrial reticulum (mitochondrial interactosome and oxidative metabolism), phosphagen and glycolytic system (extramitochondrial ATP production), the linker of nucleoskeleton and cytoskeleton complex (nesprins interaction with microtubules, actin polymerization, $\beta$-tubulins), motor proteins (e.g., myofibrillar ATPase machinery, vesicles transport), and ion pumps (e.g., SERCA, $\mathrm{Na}^{+} / \mathrm{K}^{+}$-ATPase). The cardiolipin-rich domain is represented by parallel black lines. Green sparkled circles represent the subcellular processes where the CK/PCr system is important for functionality. Several proteins of the endoplasmic reticulum-mitochondria organizing network (ERMIONE), the SERCA complex, the TIM/TOM complex, the MICOS complex, the linker of nucleoskeleton and cytoskeleton complex, and the architecture of sarcomere and cytoskeleton are not depicted for readability. ANT: adenine nucleotide translocase; CK: creatine kinase; Cr: creatine; Crn: creatinine; CRT: $\mathrm{Na}^{+} / \mathrm{Cl}^{-}$-dependent creatine transporter; ERMES: endoplasmic reticulummitochondria encounter structure; ETC: electron transport chain; GLUT-4: glucose transporter type 4; 
HK: hexokinase; mdm10: mitochondrial distribution and morphology protein 10; MICOS: mitochondrial contact site and cristae organizing system; NDPK: nucleoside-diphosphate kinase; NPC: nuclear pore complex; PCr: phosphocreatine; SAM: sorting and assembly machinery; SERCA: Sarco/Endoplasmic Reticulum $\mathrm{Ca}^{2+}$ ATPase; TIM: translocase of the inner membrane complex; TOM: translocase of the outer membrane complex; UCP: uncoupling protein; VDAC: voltage-dependent anion channel. Reprinted with permission. See Bonilla et al. [1] for more details about the metabolic basis of creatine in energy production and disease.

Numerous studies over the last three decades have shown that creatine monohydrate (CrM) supplementation (e.g., $4 \times 5 \mathrm{~g}$ /day for 5-7 days or 3-6 g/day for 4-12 weeks) increases muscle creatine and PCr content by 20-40\% [5,11-15] and brain creatine content by $5-15 \%$ [16-21]. Creatine monohydrate supplementation has been reported to safely improve high-intensity exercise performance by 10-20\% leading to greater training adaptations in adolescents [22-26], young adults [27-38], and older individuals [21,39-48]. No clinically significant side effects have been reported other than a desired weight gain [49]. Additionally, there is little to no evidence that CrM causes anecdotal reports of bloating, gastrointestinal distress, disproportionate increase in water retention, increased stress on the kidneys, increased susceptibility to injury, etc. [49,50]. In fact, studies directly assessing whether creatine causes some of those issues found no or opposite effects. As a result, there has been interest in assessing whether CrM supplementation may benefit a number of clinical populations including conditions that impair mitochondrial function [6]. The rationale is that since CrM supplementation can increase high-energy phosphate availability and also has antioxidant, neuroprotective, anti-lactatic, and calcium-homoeostatic effects, increasing phosphagen availability may help improve cell survival and/or health outcomes in conditions in which mitochondrial function is compromised (e.g., ischemia, injury, and/or non-communicable chronic diseases). The purpose of this review is to examine the literature related to the role of CrM supplementation in the management of various conditions characterized by mitochondrial dysfunction and make recommendations about further work needed in this area.

\section{Methods}

The methodological basis of this narrative review is a selective literature search in the PubMed database, supplemented by a free Internet search (German and English). In a first explorative step, the search terms "creatine supplementation" and/or "mitochondrial dysfunction" and "creatine" and/or "mitochondrial disease" were used. After a first analysis of the searched literature identifying 68 articles, a new selective literature search was performed in the sources described above using the terms mentioned above, adding relevant cited sources and cross-references. Subsequently, titles, abstracts and finally fulltext articles were examined by the scientific team with regard to the suitability of the articles in terms of content and, in a subsequent step, in terms of quality. After the qualitative criteria had been verified, the content exploration was carried out following thematic questions related to the role of creatine in context: (1) Ergogenic role in mitochondrial dysfunction; (2) Noncommunicable chronic diseases (NCD); (3) Cardiovascular disease and ischemic heart failure; (4) Traumatic and ischemic CNS injuries; (5) Neurodegenerative disorders; (6) Psychological disorders; and (7) Chronic Fatigue Syndrome, Post Viral Fatigue Syndrome and Long COVID.

\section{Creatine's Ergogenic Role in Mitochondrial Dysfunction}

Although there is not clear definition of mitochondrial dysfunction, it generally refers to conditions that reduce the ability of the mitochondria to contribute to production of energy in the form of ATP. However, any alteration of normal mitochondrial function could be called "mitochondrial dysfunction" as well [51]. Mitochondrial dysfunction can be of primary origin through inheriting pathological altered mitochondrial DNA (mtDNA) or acquiring secondary dysfunction through aging and exposure to mtDNA damaging 
processes [52,53]. This can be due to traumatic ischemic (blood deficient) or anoxic (oxygen deficient) as well as chronic conditions. Most common reasons for mitochondrial dysfunction are hypoxia, overexpression of reactive oxygen species (ROS), and an alteration of the intracellular calcium homoeostasis. Since creatine supplementation increases the availability of PCr, it may help cells withstand ischemic challenges and/or offset energy deficits associated with mitochondrial dysfunction

\subsection{Acute, Traumatic Mitochondrial Dysfunction}

Figure 2 shows the schematic sequence of an acute traumatic mitochondrial dysfunction with possible subsequent ischemia. The mechanical forces of injury result in an influx of calcium, potassium, and sodium. A calcium gradient is created, which reduces mitochondrial function [54,55]. In addition, an injury can lead to short-term ischemia (hypoxia) due to swelling, edema formation, development of neuroinflammation, obstruction of vessels, or hemorrhage [56]. The resulting oxygen deficiency interrupts the respiratory chain in the mitochondria. In both cases, the cell must switch to the energetic emergency plan and produce energy glycolytically, thereby increasing lactate production [57-61]. Oxygen radicals are generated, causing oxidative stress. This leads to cell damage and ultimately to cell death (apoptosis) [62-64]. If sufficient creatine phosphate reserves are present, the cell can compensate short-term energy deficits. ATP-dependent calcium transporters can counteract the calcium gradient under consumption of ATP and PCr, maintain the cell milieu, and thus normalize mitochondrial function [65,66]. Oxygen radicals can be intercepted [67]. Even transient hypoxia of a few seconds can be counteracted by the body in this way [68]. There is evidence that creatine and cyclocreatine inhibit the mitochondrial-creatine kinaseadenine nucleotide translocator (Mi-Cr-ANT) complex and the mitochondrial permeability transition that is associated with ischemic injury and apoptosis [69]. Additionally, creatine enhances the ability of Mi-CK to shuttle ADP for oxidative phosphorylation and $\mathrm{PCr}$ formation, thereby decreasing mitochondrial membrane and production of reactive oxygen species (ROS) [70]. Since impairment in cellular energy production and increased oxidative stress are common features in several neuromuscular degenerative diseases, creatine supplementation may provide some therapeutic benefit $[69,70]$. In support of this premise, Sakellaris et al. $[71,72]$ reported that oral administered creatine can be used as an additional supplement in treatment of acute mitochondrial dysfunction after brain injury. These studies showed clear improvement in clinical outcomes of patients with additional creatine-supplementation in comparison to no creatine-intake. Table 1 shows the level of evidence in humans that creatine supplementation may have a positive effect on treatment outcomes in patients with traumatic brain injury.

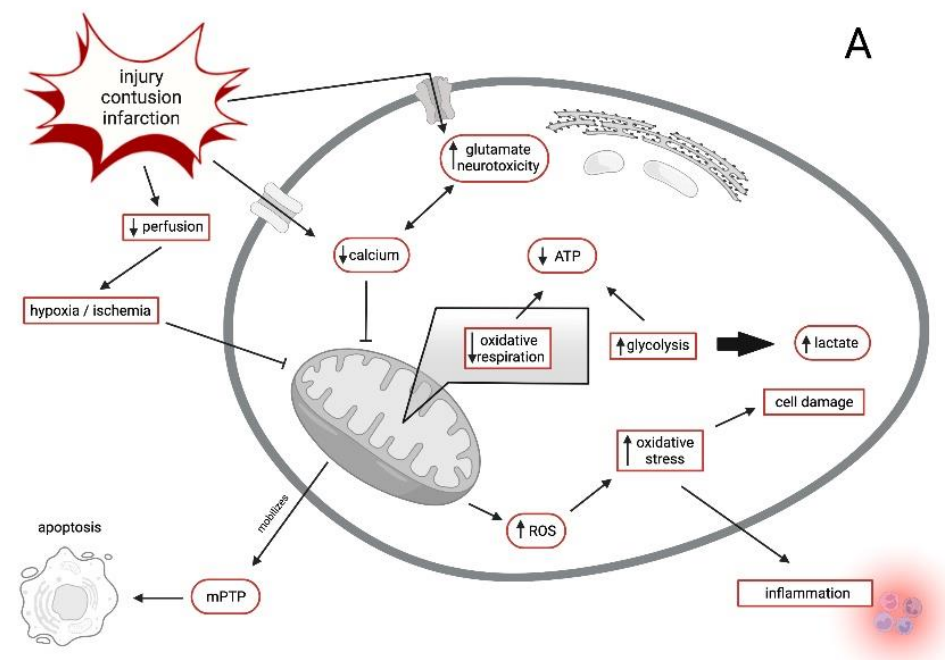

Figure 2. Cont. 


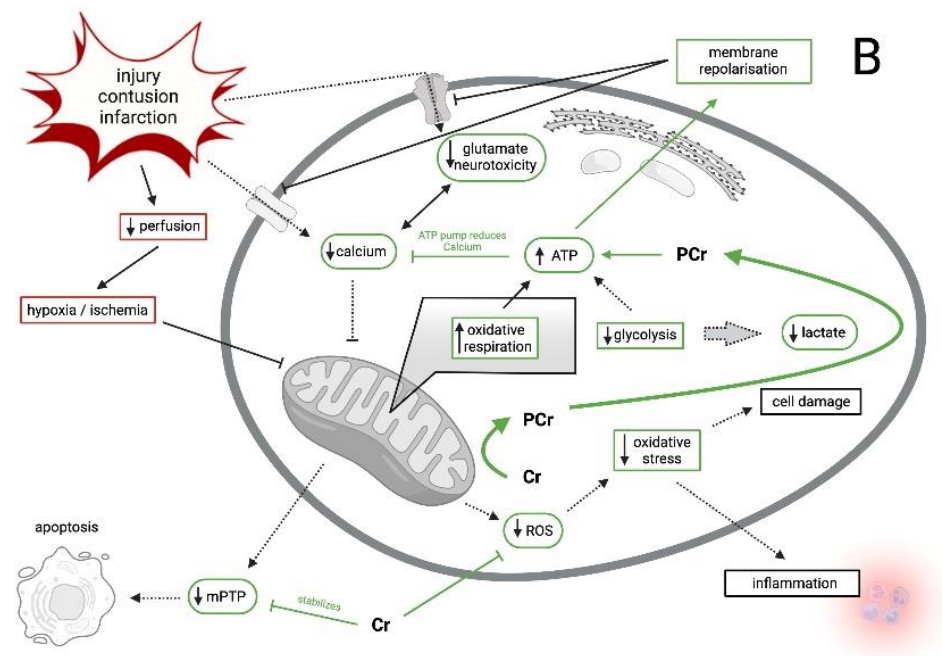

Figure 2. Panel A: Intracellular cascade after injury, infarction or contusion leads to mitochondrial dysfunction. Panel B: Impact of creatine on mitochondrial dysfunction. Green shows direct increase/stimulation of $\mathrm{Cr} / \mathrm{PCr}$, red shows direct decrease/inhibition of $\mathrm{Cr} / \mathrm{PCr}$, dotted line represents indirect impact of $\mathrm{Cr} / \mathrm{PCr}$ on cellular pathways. ATP is adenosine triphosphate; $\mathrm{Cr}$ is creatine; $\mathrm{PCr}$ is phosphocreatine; ROS is reactive oxygen species; $\mathrm{mPTP}$ is mitochondrial permeability transition pore. Adapted from Dean et al. [55].

Table 1. Level of evidence for creatine supplementation in acute traumatic mitochondrial dysfunction.

\begin{tabular}{llllllll}
\hline Study & Disease & Subject & Treatment & Randomized & Subjects & Efficacy & Effect Role \\
\hline $\begin{array}{l}\text { Sakellaris } \\
\text { et al. [71] }\end{array}$ & $\begin{array}{l}\text { Traumatic } \\
\text { brain injury }\end{array}$ & Human & $\begin{array}{l}0.4 \mathrm{~g} / \mathrm{kg} \text { per } \\
\text { day for } \\
6 \text { months }\end{array}$ & Yes & 39 & $\begin{array}{l}\text { Improved self-care, } \\
\text { cognition, behavior } \\
\text { functions and } \\
\text { communication }\end{array}$ & $\begin{array}{l}\text { Direct } \\
\text { effect on } \\
\text { disease }\end{array}$ \\
$\begin{array}{l}\text { Sakellaris } \\
\text { et al. [72] }\end{array}$ & $\begin{array}{l}\text { Traumatic } \\
\text { brain injury }\end{array}$ & Human & $\begin{array}{l}0.4 \mathrm{~g} / \mathrm{kg} \text { per } \\
\text { day for } \\
6 \text { months }\end{array}$ & Yes & 39 & $\begin{array}{l}\text { Reduced fatigue, } \\
\text { headache and dizziness }\end{array}$ & $\begin{array}{l}\text { effect on } \\
\text { disease }\end{array}$ \\
\hline
\end{tabular}

\subsection{Chronic, Atraumatic Mitochondrial Dysfunction}

Many chronic diseases such as cancer and age-related pathological conditions have been related to an altered mitochondrial function [73-101]. Chronic mitochondrial dysfunction is usually caused by slow changes in mitochondrial homeostasis eventually leading to an increase in ROS/NOS, glycolysis, and hyper-acidosis. There are multiple factors that directly damage mitochondrial function (Figure 3). Hypoxia is a common factor in conditions such as solid tumor, ischemia, or inflammation that leads to a depletion of oxygen and eventually through production of ROS to an alteration of intracellular proteins, lipids and DNA [89]. On the other hand, research was able to prove that malignant cells tend to create energy under glycolytic conditions although sufficient oxygen is provided. This pathological mechanism is called "Warburg Effect" [102,103]. This leads to an increase in cell acidity and an increase in ROS with damaging of DNA. Other factors leading to chronic mitochondrial dysfunction are toxic metals or reactive nitrogen species (NOS) [104]. An increase in ingested carbohydrates bigger than the individual needs leads to hyperinsulinemia. As a chronic condition, this will lead to an increase in receptor for advanced glycation end products (RAGE). Thus, nitrosative stress increases, manipulating mitochondrial function [105-109]. Increasing stress will lead to an intracellular accumulation of ammonium [110-112], ROS [113], lactate [114], ultimately inhibiting the Krebs cycle and oxidative metabolism. 


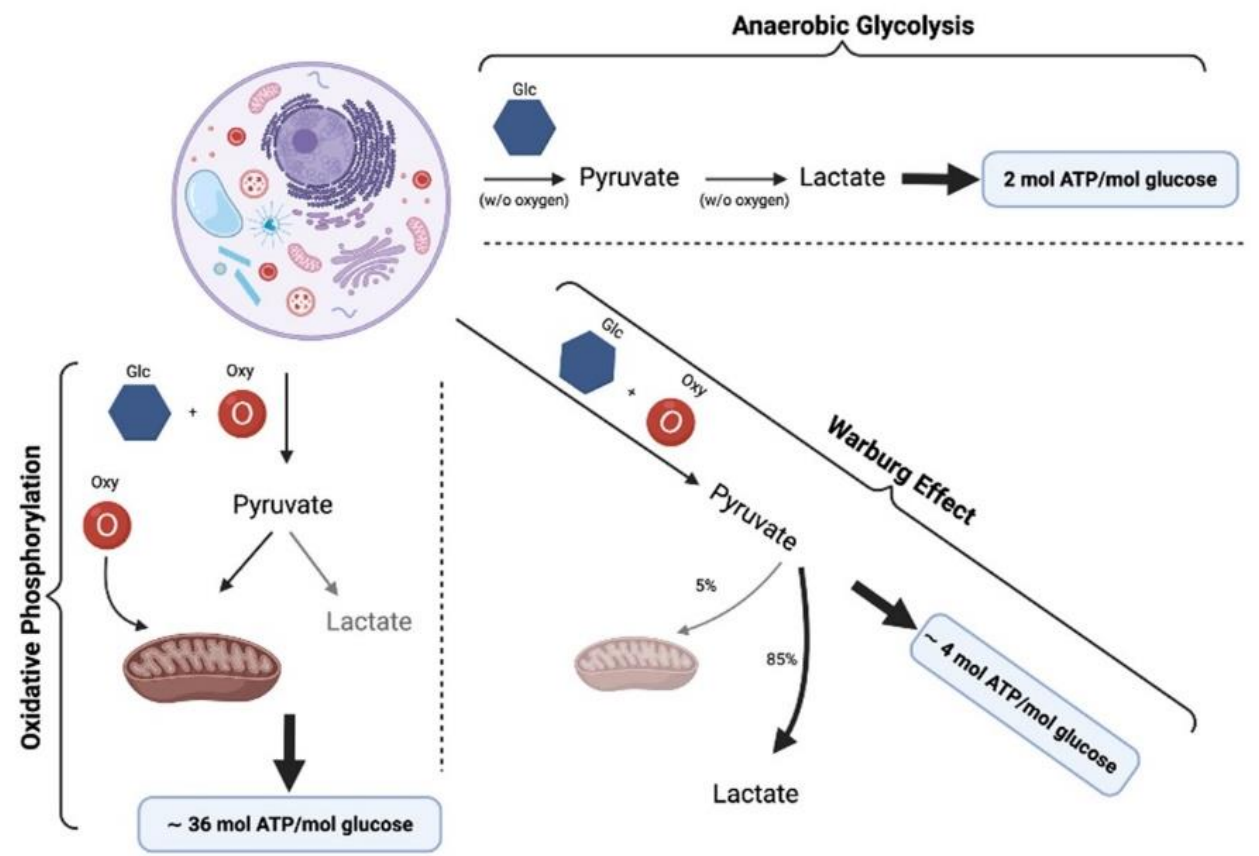

Figure 3. Warburg Effect: glycolysis produces 2 ATP instead of 36 ATP, in pathological tissues even despite aerobic conditions. Glc is glucose, Oxy is oxygen, ATP is adenosine triphosphate. Adapted from Vander Heiden et al. [91].

Typical factors that lead to a disturbance in the cellular respiration are hypoxia, inflammation, viruses, mutations, oncogenes, age, radiation, and carcinogens [115]. The ultimate, most common denominators are reactive species which damage mtDNA. As soon as cellular defense systems such as antioxidants, intracellular energetic buffer, and enzymatic reactions are worn down, chronic alteration of cellular organelles begins [116]. As mentioned above, it is hard to differentiate in chronic mitochondrial dysfunction whether pathological conditions lead to hypoxia that produces ROS/NOS which eventually harms mtDNA or whether an altered mtDNA leads to an overexpression of ROS/NOS damaging itself [117]. It is widely accepted, however, that this chronic status is a vicious circle leading to a lethal cellular condition harming the host.

Magnetic resonance spectroscopy (MRS) is an analytical tool that detects electromagnetical signals that are produced by the atomic nuclei within the molecules. Thus, it can be used to (non-invasively) measure concentrations for specific molecules in tissue. This technique has extensively been used in neurological research to identify phosphorus and proton metabolites in tissue in vivo [118-121]. Using this, research was able to prove mitochondrial dysfunction in patients with bipolar disorders. These patients also suffered from an impaired energy production [122], increased levels of lactate (hyperacidotic state) [123] and PCr concentration $[114,124,125]$. Therefore, it was assumed that creatine supplementation could improve clinical outcome in cases of mitochondrial dysfunction. Creatine is able to buffer lactate accumulation by reducing the need for glycolysis [126], reducing ROS [127] and restoring calcium homeostasis. Table 2 presents an overview of the level of evidence for creatine supplementation for chronic, atraumatic mitochondrial dysfunction. 
Table 2. Level of evidence for creatine supplementation for chronic, atraumatic mitochondrial dysfunction.

\begin{tabular}{llllllll}
\hline Study & Disease & Subject & Treatment & Randomized & Subjects & Efficacy & Effect Role \\
\hline $\begin{array}{l}\text { Guimarães- } \\
\begin{array}{l}\text { Ferreira et al. } \\
{[128]}\end{array}\end{array}$ & & $\begin{array}{l}\text { Animal } / \\
\text { vitro }\end{array}$ & $\begin{array}{l}5 \mathrm{~g} / \mathrm{kg} \text { per } \\
\text { day for } \\
\text { 6 days }\end{array}$ & no & 39 & $\begin{array}{l}\text { Decrease in ROS in } \\
\text { muscle tissue }\end{array}$ & Anima model \\
Kato et al. & $\begin{array}{l}\text { Bipolar } \\
\text { disorder }\end{array}$ & Humans & None & No & $\begin{array}{l}25 \text { (disease) } \\
\text { vs. 21 } \\
\text { (control) }\end{array}$ & $\begin{array}{l}\text { Abnormal energy } \\
\text { phosphate } \\
\text { metabolism in } \\
\text { bipolar disorder }\end{array}$ & $\begin{array}{l}\text { No intervention, } \\
\text { only descriptive, } \\
\text { observational } \\
\text { findings }\end{array}$ \\
\hline
\end{tabular}

\section{Noncommunicable Chronic Diseases (NCD)}

Modern ways of (unhealthy) living like over nutrition, exposure to toxic substances, and sedentarism combined with an individual's genetic background led to the development of NCD [90]. Four disease clusters are associated with NCD such as cardiovascular diseases, cancers, chronic pulmonary diseases, and diabetes mellitus [129]. NCD are associated with low-grade inflammation and an increase in oxidative stress [130]. Through the past decades, they have become the biggest health threat of modern society [131-133]. Lately, there has been a link established between NCD and mitochondrial dysfunction. Reduced oxygen consumption rates have been shown in cardiovascular diseases such as hypertension and atherosclerosis. Additionally, they suffer from calcium overload due to mitochondrial calcium mishandling and ROS overproduction [134-137]. Obesity [138-141] as well as diabetes mellitus [142-149] are associated with an increased mitochondrial fragmentation rate, impaired ATP production, as well as ROS overproduction and calcium mishandling. In regards to creatine and its connection to mitochondrial dysfunction, reduced levels were detected in human myocytes in diabetes mellitus [150], obesity [151], and hypertension [152]. Not surprisingly, NCD are the most common factors contributing to the development of an acute ischemic heart attack or acute ischemic brain disease (Figure 4).

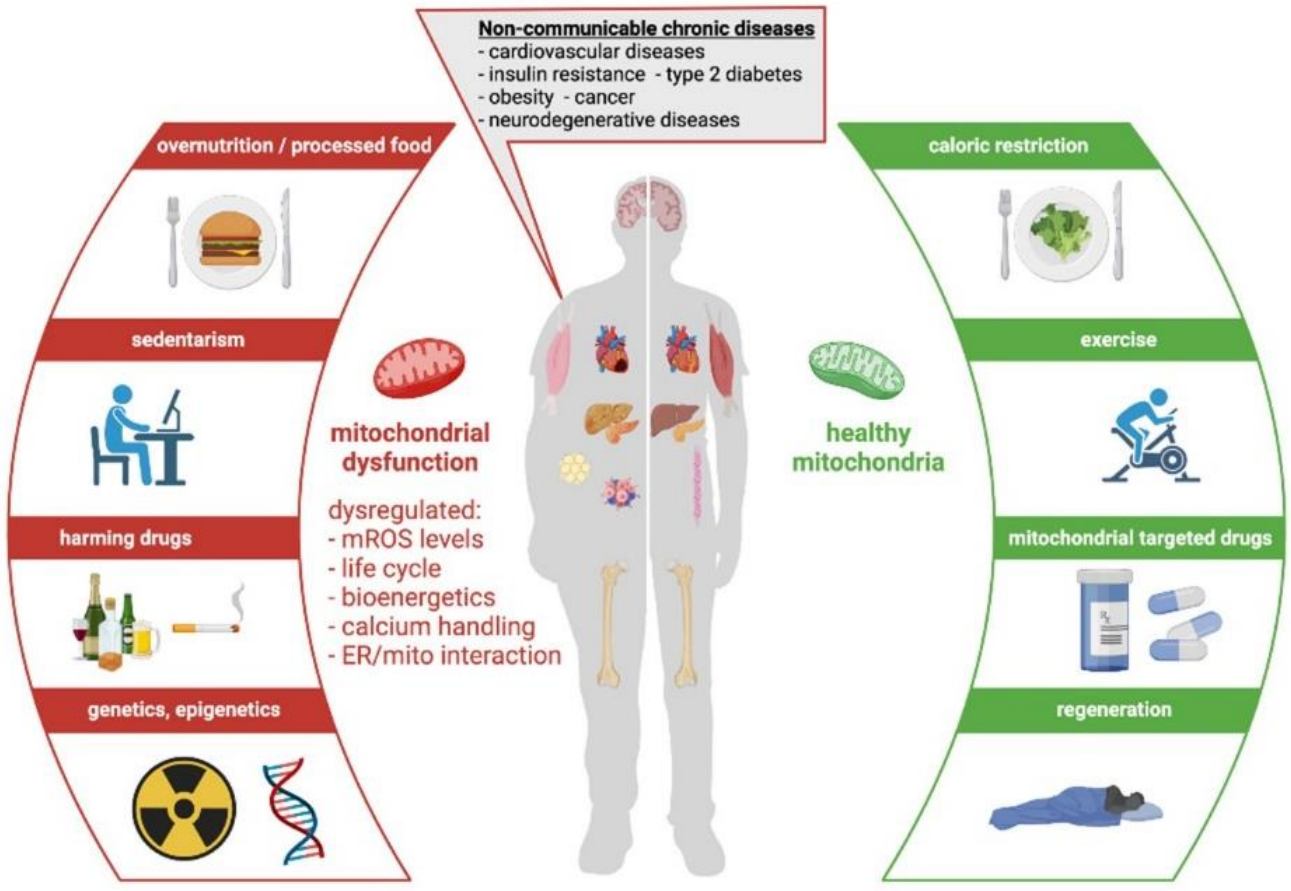

Figure 4. Mitochondrial dysfunction and non-communicable diseases. Adapted from Diaz-Vegas et al. [90]. 
Table 3 shows some of the studies that have been conducted on creatine supplementation in noncommunicable chronic diseases. Creatine's benefits in physical activity and thus counteracting NCD development have been widely explained [20,153-163]. There is, however, substantial evidence for the beneficial effects of supplementation even without combining it with sports. The sole intake of creatine has been able to significantly lower blood lipids such as cholesterol and triglycerides, slow down the development of fatty liver, and lower the $\mathrm{HbA} 1 \mathrm{C}$ in human and animal studies, thus improving the clinical outcome and progression of the metabolic syndrome [164-166].

Table 3. Level of evidence of creatine's role in noncommunicable chronic disease.

\begin{tabular}{|c|c|c|c|c|c|c|c|}
\hline Study & Disease & Subject & Treatment & Randomized & Subjects & Efficacy & Effect Role \\
\hline $\begin{array}{l}\text { Rider et al. } \\
\text { [151] }\end{array}$ & Obesity & Human & None & None & 64 & $\begin{array}{l}\text { Deranged cardiac } \\
\text { energetics and diastolic } \\
\text { dysfunction in obesity } \\
\text { group }\end{array}$ & $\begin{array}{l}\text { Observational, } \\
\text { disease related } \\
\text { changes in } \\
\text { metabolism }\end{array}$ \\
\hline $\begin{array}{l}\text { Scheuermann- } \\
\text { Freestone et al. } \\
\text { [150] }\end{array}$ & $\begin{array}{l}\text { Diabetes } \\
\text { Type } 2\end{array}$ & Human & None & None & 36 & $\begin{array}{l}\text { Impaired myocardial and } \\
\text { skeletal muscle } \\
\text { metabolism (reduced } \\
\text { PCR/ATP ratio) }\end{array}$ & $\begin{array}{l}\text { Observational } \\
\text { disease related } \\
\text { changes in } \\
\text { metabolism }\end{array}$ \\
\hline $\begin{array}{l}\text { Lamb et al. } \\
\text { [152] }\end{array}$ & Hypertension & Human & None & None & 24 & $\begin{array}{l}\text { Altered high-energy } \\
\text { phosphate metabolism in } \\
\text { hypertension. Cardiac } \\
\text { dysfunction correlates } \\
\text { with metabolic alterations }\end{array}$ & $\begin{array}{l}\text { Observational, } \\
\text { disease related } \\
\text { changes in } \\
\text { metabolism }\end{array}$ \\
\hline $\begin{array}{l}\text { Gualano et al. } \\
\text { [164] }\end{array}$ & $\begin{array}{l}\text { Diabetes } \\
\text { Type } 2\end{array}$ & Human & $\begin{array}{l}5 \mathrm{~g} \text { creatine for } 12 \\
\text { weeks + physical } \\
\text { activity program }\end{array}$ & Yes & 25 & $\begin{array}{l}\text { Improved glycemic } \\
\text { control in } \\
\text { supplementation group } \\
\text { (by GLUT-4 recruitment) }\end{array}$ & $\begin{array}{l}\text { Direct effect on } \\
\text { disease related } \\
\text { metabolic } \\
\text { effects }\end{array}$ \\
\hline $\begin{array}{l}\text { Earnest et al. } \\
\text { [165] }\end{array}$ & $\begin{array}{l}\text { Hyper- } \\
\text { cholester- } \\
\text { inaemia }\end{array}$ & Human & $\begin{array}{l}4 \times 5 \text { g creatine for } \\
5 \text { days and } \\
\text { afterwards } 2 \text { times } \\
\text { per day for } 51 \text { days } \\
\text { (orally) }\end{array}$ & Yes & 34 & $\begin{array}{l}\text { Minor reduction of total } \\
\text { cholesterol during } \\
\text { supplementation. } \\
\text { Reduction of } \\
\text { triacylglycerol's and very- } \\
\text { low-density-lipoprotein c } \\
4 \text { weeks after finishing } \\
\text { supplementation }\end{array}$ & $\begin{array}{l}\text { Direct effect of } \\
\text { supplementa- } \\
\text { tion on } \\
\text { metabolism. }\end{array}$ \\
\hline $\begin{array}{l}\text { Deminice et al. } \\
\text { [166] }\end{array}$ & Fatty liver & Animal & $\begin{array}{l}\text { Control vs. } 0.25 \% \\
\text { choline diet vs. } \\
0.25 \% \text { choline }+2 \% \\
\text { creatine diet }\end{array}$ & None & 24 & $\begin{array}{l}\text { Prevention of fat liver } \\
\text { accumulation and hepatic } \\
\text { events in creatine-fed } \\
\text { group }\end{array}$ & Animal model \\
\hline
\end{tabular}

\section{Cardiovascular Disease and Ischemic Heart Failure}

Optimal replenishment of creatine reserves was able (in experimental studies) to slow down disease progression of the other above mentioned NCD and cardiomyopathy. Therefore, creatine supplementation has been identified to be of special therapeutic interest in treatment of cardiovascular diseases and their course $[167,168]$. The heart has its own four creatine kinase (CK) isozymes, proving the importance of ensuring filled energy depots [169]. A gradual reduction of myocardial total creatine content has been shown on chronic heart failure in human as well as animal studies [170-173]. The ratio of PCr/ATP has been defined to better judge myocardial creatine metabolism [174]. Low ratios have been positively correlated with low contractile function, more severe heart failure symptoms, and a higher risk of mortality [175-177].

Creatine supplementation in patients with chronic heart failure and similar animal studies have not shown any beneficial effect on clinical outcome, neither on myocardial creatine concentrations [178-180]. The transmembrane Creatine-Transporter (CrT) seems to be the limiting factor in this matter [181]. Question remains if other creatine-analogues that pass intracellular without the need of CrT might prove of better help in cardiovascular diseases. The energy deficiency resulting from local hypoxia during an ischemic heart attack leads to mitochondrial dysfunction, which in turn can have arrhythmogenic consequences and lead to sudden cardiac death [182-184]. Therefore, it is not surprising that creatine 
plays a critical role during a cardiac ischemic event $[185,186]$. First in vitro studies allow the hypothesis that saturation of myocardial creatine stores may lead to protection in the event of a transient ischemic attack [49]. In this context, in animal studies, filled ATP stores have a positive inotropic, apoptosis-protective effect and counteract a post-ischemic inflammatory cascade [187].

Intravenous in vivo administration of phosphocreatine was able to confer significant myocardial protection after bypass surgery [188], resulting in a reduction in the incidence of ventricular fibrillation and myocardial infarction as well as arrhythmias [189]. The newly developed special form of creatine, cyclo-creatine, deserves special attention. After an oral loading phase prior to elective cardiac interventions (PCI, ACVB, HTX), cyclo-creatine has a similar protective effect against lethal events [183,187,190,191]. However, large-scale human studies have yet to confirm the initial promising results. Table 4 summarizes the level of evidence available on the role of creatine in cardiovascular disease and ischemic heart failure [187-191].

Table 4. Level of evidence for creatine supplementation for chronic, atraumatic mitochondrial dysfunction.

\begin{tabular}{|c|c|c|c|c|c|c|c|}
\hline Study & Disease & Subject & Treatment & Randomized & Subjects & Efficacy & Effect Role \\
\hline $\begin{array}{l}\text { Elgebaly } \\
\text { et al. [187] }\end{array}$ & - & $\begin{array}{l}\text { Animal/ } \\
\text { vitro }\end{array}$ & $\begin{array}{l}500 \mathrm{mg} / \mathrm{kg} \\
\text { BW }\end{array}$ & no & 6 & $\begin{array}{l}\text { Better aortic flow, } \\
\text { coronary flow, cardiac } \\
\text { output, stroke volume, } \\
\text { and stroke work }\end{array}$ & $\begin{array}{l}\text { Animal } \\
\text { model }\end{array}$ \\
\hline $\begin{array}{l}\text { Cisowski } \\
\text { et al. [188] }\end{array}$ & $\begin{array}{l}\text { Cardiac } \\
\text { surgery }\end{array}$ & Humans & $\begin{array}{l}6 \mathrm{~g} 3 \text { days } \\
\text { pre-surgery, } \\
\text { intra-surgical } \\
\text { and two days } \\
\text { post- surgery } \\
\text { i.v. }\end{array}$ & yes & 40 & $\begin{array}{l}\text { Reduced arrhythmic } \\
\text { events, reduced need } \\
\text { of ionotropic } \\
\text { medication }\end{array}$ & $\begin{array}{l}\text { Direct effect } \\
\text { on surgical } \\
\text { procedure }\end{array}$ \\
\hline $\begin{array}{l}\text { Ruda et al. } \\
\text { [189] }\end{array}$ & $\begin{array}{l}\text { Ischemic } \\
\text { myocardial } \\
\text { infarct }\end{array}$ & human & $\begin{array}{l}2 \mathrm{~g} \text { bolus }+4 \\
\mathrm{~g} / \mathrm{h} \text { over } 2 \mathrm{~h}\end{array}$ & Yes & 60 & $\begin{array}{l}\text { Reduced arrhythmic } \\
\text { events }\end{array}$ & $\begin{array}{l}\text { Direct effect } \\
\text { on short term } \\
\text { outcome }\end{array}$ \\
\hline $\begin{array}{l}\text { Chida et al. } \\
\text { [192] }\end{array}$ & $\begin{array}{l}\text { Dilated } \\
\text { Cardio- } \\
\text { myopathy }\end{array}$ & Human & None & None & 13 & $\begin{array}{l}\text { Plasma BNP level was } \\
\text { correlated negatively } \\
\text { with the myocardial } \\
\text { phosphocrea- } \\
\text { tine/adenosine } \\
\text { triphosphate }\end{array}$ & $\begin{array}{l}\text { Observational } \\
\text { finding }\end{array}$ \\
\hline $\begin{array}{l}\text { Roberts } \\
\text { et al. [191]. }\end{array}$ & None & Animal & $\begin{array}{l}\text { Oral creatine- } \\
\text { feeding }\end{array}$ & None & Not clear & $\begin{array}{l}\text { Higher cellular ATP } \\
\text { during ischemia in } \\
\text { creatine-fed rat hearts }\end{array}$ & $\begin{array}{l}\text { Animal } \\
\text { model }\end{array}$ \\
\hline
\end{tabular}

\section{Traumatic and Ischemic Central Nervous System Injuries}

Mitochondrial function and ATP production are crucial for the neuronal survival and excitability [193]. At the same time, however, mitochondrial dysfunction leads to the overproduction of ROS and neuronal apoptosis which is closely related to neurodegenerative diseases and cerebral ischemia [193-197]. Whereas earlier research mainly focused on mitochondrial bioenergetic roles, new studies have shown the importance of apoptotic signaling, mitochondrial biogenesis, and mitophagy in the development of cerebrovascular disease and stroke. Mitochondrial health is therefore essential for neurological survival and rehabilitation [198,199]. Reperfusion injury is another acute complication feared by medical doctors involving mitochondria and clinical outcomes [200,201]. Following reperfusion of the injured brain tissue, excessive ROS and calcium produced under hypoxic conditions are washed in the body's periphery, causing damage on cellular and molecular level [202]. Intracellular calcium deregulation enhances neuronal cell death after stroke, giving the stability of the mitochondrial (calcium) permeability transition pore (mPTP) a special predictive measure [203]. 
The acute protective effects of creatine on the central nervous system (CNS) have long been known. Similar to the effect in the myocardium, energy buffering for shortterm hypoxic conditions can be achieved by saturating intracellular PCr. This may lead to protection against ischemia and cell death, as well as calcium gradients created by mechanical stimuli [204-206]. In animal experiments, researchers were able to show that idiopathically caused brain damage and spinal cord injuries developed to a lesser extent after creatine oral administration $[207,208]$. Creatine supplementation also had a positive effect on infarct sizes after insult in ischemic mouse models [209]. These results suggest that creatine administration may lead to preventive CNS protection against concussions, traumatic brain injury, spinal cord injury, and insults [210].

Adding to the above-mentioned protective effects of Creatine during a hypoxic situation, special advantages of creatine on the CNS have been proven. The term excitotoxicity describes the destruction of neuronal cells due to pathological activation of its excitatory receptors [202]. Research was able to show that excitatory amino acids, such as Glutamate, become more neurotoxic when the cell's energy levels are reduced by hypoxia [211]. Activation of the glutamate NMDA receptor correlates with reduced ATP and PCr levels [212]. Creatine was able to protect animal brain tissues from the apoptotic effects of excitatory amino acids [213,214]. Lastly, it was shown that Creatine stabilizes mPTP in rodent studies, thus protecting brain tissue from apoptosis and cell death [67]. Table 5 presents a summary of the level of evidence related to creatine supplementation for traumatic and ischemic CNS injuries [205-207].

Table 5. Level of evidence for the role of creatine supplementation in individuals with traumatic and ischemic CNS injuries.

\begin{tabular}{|c|c|c|c|c|c|c|c|}
\hline Study & Disease & Subject & Treatment & Randomized & Subjects & Efficacy & Effect Role \\
\hline $\begin{array}{l}\text { Zhu et al. } \\
\text { [206] }\end{array}$ & $\begin{array}{l}\text { None/induced } \\
\text { ischemia }\end{array}$ & Animal & $\begin{array}{l}2 \% \text { creatine- } \\
\text { supplemented } \\
\text { diet for } 4 \text { weeks }\end{array}$ & None & $\begin{array}{l}6 \text { per } \\
\text { group }\end{array}$ & $\begin{array}{l}\text { Reduction in } \\
\text { ischemia induced } \\
\text { infarct size }\end{array}$ & $\begin{array}{l}\text { Animal } \\
\text { model }\end{array}$ \\
\hline $\begin{array}{l}\text { Turner et al. } \\
\text { [205] }\end{array}$ & $\begin{array}{l}\text { None/induced } \\
\text { hypoxia }\end{array}$ & Human & $\begin{array}{l}\text { 7-ds oral creatine- } \\
\text { supplementation }\end{array}$ & Yes & 15 & $\begin{array}{l}\text { Less decrease in } \\
\text { cognitive } \\
\text { performance, } \\
\text { attentional } \\
\text { capacity, } \\
\text { corticomotor } \\
\text { excitability for } \\
\text { creatine-group }\end{array}$ & $\begin{array}{l}\text { Human } \\
\text { brain } \\
\text { metabolism }\end{array}$ \\
\hline $\begin{array}{l}\text { Hausmann } \\
\text { et al. [207] }\end{array}$ & $\begin{array}{l}\text { None/induced } \\
\text { spinal cord } \\
\text { injury }\end{array}$ & Animal & $\begin{array}{l}4 \text { weeks oral } \\
\text { creatine- } \\
\text { supplementation }\end{array}$ & none & 20 & $\begin{array}{l}\text { Better locomotor } \\
\text { scores after } 1 \text { week } \\
\text { for creatine-group. } \\
\text { Less scar tissue for } \\
\text { creatine-group } \\
\text { after } 2 \text { weeks }\end{array}$ & $\begin{array}{l}\text { Animal } \\
\text { model }\end{array}$ \\
\hline $\begin{array}{l}\text { Sullivan } \\
\text { et al. [208] }\end{array}$ & $\begin{array}{l}\text { None/induced } \\
\text { traumatic brain } \\
\text { injury }\end{array}$ & Animal & $\begin{array}{l}\text { Mice: } 0.1 \mathrm{~mL} / 10 \\
\mathrm{~g} / \mathrm{BW} \text { creatine } \\
\text { monohydrate } \\
\text { injection for } 1,3 \\
\text { or } 5 \text { days } \\
\text { Rats: } 1 \% \text { creatine } \\
\text { diet for } 4 \text { weeks. }\end{array}$ & none & $\begin{array}{l}40 \text { mice/ } \\
24 \text { rats }\end{array}$ & $\begin{array}{l}\text { Reduction of brain } \\
\text { tissue damage size } \\
\text { by } 36 \% \text { mice and } \\
50 \% \text { rats }\end{array}$ & $\begin{array}{l}\text { Animal } \\
\text { model }\end{array}$ \\
\hline $\begin{array}{l}\text { Prass et al. } \\
\text { [209] }\end{array}$ & $\begin{array}{l}\text { None/induced } \\
\text { experimental } \\
\text { stroke }\end{array}$ & Animal & $\begin{array}{l}\text { Creatine-rich } \\
\text { diet }(0 \%, 0.5 \% \text {, } \\
1 \%, 2 \% \text { for } 3 \\
\text { weeks }\end{array}$ & None & Unclear & $\begin{array}{l}\text { Reduction of } \\
\text { infarct size by } 40 \% \\
\text { in } 2 \% \text { creatine-fed } \\
\text { group }\end{array}$ & $\begin{array}{l}\text { Animal } \\
\text { model }\end{array}$ \\
\hline
\end{tabular}




\section{Neurodegenerative Disorders}

Ageing has been defined as a "progressive accumulation of changes with time that are associated with or responsible for the ever-increasing susceptibility to disease and death" [215]. Brain tissue is due to its high-energy demands especially vulnerable to mitochondrial deficits, ROS, hypoxia, and energy depletion [216,217]. Although ROS are of special need to neurons and brain tissue needed for synaptic plasticity, learning and memory function, their overproduction is closely related to nitration of proteins, mtDNA impairment and the development of neurodegenerative diseases, ageing, and cognitive deficits [218-220]. Insulin resistance and diabetes mellitus deteriorate these conditions and accelerate cognitive decline as well as incidence of neurogenerative diseases [221223]. RAGE and ammonium level up the documented damage to mitochondria, neuronal cells, and brain tissue [224-226]. Alzheimer's disease has already been named "type 3 diabetes" [227]. Pathologically altered mitochondria have been shown to be swollen, have altered membrane potential, and reductions of ATP levels [228]. Therefore, mitochondrial protection and reduction of oxidative stress have been suggested to be of high therapeutic importance for the treatment of neurodegenerative disorders [229]. Anti-inflammatory nutrition, caloric restriction, as well as the use of supplements have been discussed to be improve mitochondrial functioning and cognition [230-233]. Various studies have also shown that creatine supplementation has a positive effect on cognition and brain function $[234,235]$. The effect was greater the more the participant was exposed to external stressors (e.g., hypoxia, sleep deprivation, etc.) $[45,205]$ or the more complex the tasks were performed [236]. In this context, intake led to a lower need for sleep, earlier wake-up times, and improved sleep behavior [237].

Neurodegenerative diseases are usually characterized by the destruction or dysfunction of neurons in a specific brain area. Depending on the affected brain area, course, and severity, the forms of the disease differ. These include Alzheimer's disease (MA), amyotrophic lateral sclerosis (ALS), multiple sclerosis (MS), Huntington's disease (MH), and Parkinson's disease (MP). Impaired energy balance with mitochondrial dysfunction and oxidative stress are common to all diseases [238]. Similar findings have been made with intellectual disability-related diseases [239]. This bioenergetic deficit is thought to lead to apoptosis and necrosis and ultimately to neuronal degeneration [240]. Therefore, it is reasonable to assume that an improvement in mitochondrial health could enable a positive influence on the course of the disease. Table 6 provides a summary of the level of evidence related to the role of creatine supplementation for neurodegenerative disorders $[45,234,236]$. Initial studies suggest that creatine supplementation may be neuroprotective. For example, in 2013, Kley and coworkers [241] conducted a Cochrane review on the role of creatine monohydrate supplementation for treating muscle disorders. The researchers found sound evidence from randomized clinical trials that creatine supplementation increased strength and functional capacity in muscular dystrophy and idiopathic inflammatory myopathy while having no effect in patients with metabolic-related myopathies and McArdle disease. More long-term research is needed to evaluate the long-term effects of creatine in neurodegenerative diseases that impair muscle function. 
Table 6. Level of evidence for the role of creatine supplementation in individuals with neurodegenerative disorders.

\begin{tabular}{|c|c|c|c|c|c|c|c|}
\hline Study & Disease & Subject & Treatment & Randomized & Subjects & Efficacy & Effect Role \\
\hline $\begin{array}{l}\text { Hammett } \\
\text { et al. [234] }\end{array}$ & None & Human & $\begin{array}{l}20 \mathrm{~g} / \mathrm{d} \\
\text { creatine for } 5 \\
\text { days }+5 \mathrm{~g} / \mathrm{d} \\
\text { for } 2 \text {-days }\end{array}$ & Yes & 22 & $\begin{array}{l}\text { Reduction of stress related } \\
\text { blood oxygen level } \\
\text { dependent in fMRI in } \\
\text { creatine-group }\end{array}$ & $\begin{array}{l}\text { Human } \\
\text { metabolic } \\
\text { response }\end{array}$ \\
\hline $\begin{array}{l}\text { Watanabe } \\
\text { et al. [235] }\end{array}$ & None & Human & $\begin{array}{l}8 \mathrm{~g} / \mathrm{d} \text { for } \\
\text { 5-days }\end{array}$ & Yes & 24 & $\begin{array}{l}\text { Reduction of mental fatigue } \\
\text { and increased brain oxygen } \\
\text { consumption in } \\
\text { creatine-group }\end{array}$ & $\begin{array}{l}\text { Human } \\
\text { metabolic } \\
\text { response }\end{array}$ \\
\hline $\begin{array}{l}\text { McMorris } \\
\text { et al. [236] }\end{array}$ & None & Human & $4 \times 5 g / d$ & yes & 20 & $\begin{array}{l}\text { Better in central complex } \\
\text { executive tasks with creatine } \\
\text { while sleep deprivation }\end{array}$ & $\begin{array}{l}\text { Human } \\
\text { metabolic } \\
\text { response }\end{array}$ \\
\hline $\begin{array}{l}\text { McMorris } \\
\text { et al. [45] }\end{array}$ & None & Human & $4 \times 5 \mathrm{~g} / \mathrm{d}$ & Yes & 15 & $\begin{array}{l}\text { random number generation, } \\
\text { forward number and spatial } \\
\text { recall, and long-term } \\
\text { memory }\end{array}$ & $\begin{array}{l}\text { Human } \\
\text { metabolism }\end{array}$ \\
\hline
\end{tabular}

\section{Psychological Disorders}

In the 1980s, a link was established between bioenergetic deficits and depression [190, 242-244], bipolar disorders [114,245,246], and obsessive-compulsive disorders $[247,248]$. It is believed that there is an increase in energy demand with depletion of $\mathrm{PCr}$ stores at the onset of disease [124,249]. In clinical trials with depressed patients [250-252], a positive effect on subjective impairment after adjuvant creatine supplementation could be demonstrated. The higher the increase in cerebral $\mathrm{PCr}$ after creatine supplementation, the lower the depressive or manic symptoms [253]. The combination of antidepressants and creatine was more effective than simple pharmacological medication [254]. Creatine administration was even effective when drug therapy with SSRIs proved to be ineffective [255]. In this content, creatine has also been discussed as a potential therapeutic agent in the treatment of drug addiction and its psychic related disorders [256]. Positive effects of creatine supplementation have also been reported in post-traumatic stress disorders [257]. Schizophrenic and stress patients seem to gain no benefit from creatine intake. There is, however, ongoing debate on higher dosage for a needed benefit in these sub-groups [258]. Table 7 presents a summary of the literature related to the effects of creatine supplementation on individuals with psychological disorders [251,252,255].

Table 7. Level of evidence for the role of creatine supplementation in individuals with psychological disorders.

\begin{tabular}{|c|c|c|c|c|c|c|c|}
\hline Study & Disease & Subject & Treatment & Randomized & Subjects & Efficacy & Effect Role \\
\hline $\begin{array}{l}\text { Kondo } \\
\text { et al. [250] }\end{array}$ & $\begin{array}{l}\text { Adolescent } \\
\text { major } \\
\text { depressive } \\
\text { disorder }\end{array}$ & Human & $\begin{array}{l}4 \mathrm{~g} / \mathrm{d} \text { creatine } \\
\text { for } 8 \text { weeks }\end{array}$ & None & 15 & $\begin{array}{l}\text { Reduction in } \\
\text { children-depression } \\
\text { symptom scores. } \\
\text { Significant increase in } \\
\text { brain phosphocreatine } \\
\text { level. }\end{array}$ & $\begin{array}{l}\text { Direct effect on } \\
\text { disease (no } \\
\text { RCT) }\end{array}$ \\
\hline $\begin{array}{l}\text { Roitman } \\
\text { et al. [251] }\end{array}$ & $\begin{array}{l}\text { Treatment } \\
\text { resistant } \\
\text { depression }\end{array}$ & Human & $\begin{array}{l}3-5 \mathrm{~g} / \mathrm{d} \\
\text { creatine for } 4 \\
\text { weeks }\end{array}$ & None & $\begin{array}{l}8 \text { unipolar } \\
\text { depressed } \\
\text { patients and } \\
\text { two bipolar } \\
\text { patients }\end{array}$ & $\begin{array}{l}\text { Development of } \\
\text { hypomania/mania in } \\
\text { bipolar patients. } \\
\text { Improved Hamilton } \\
\text { Depression Rating } \\
\text { Scale, Hamilton } \\
\text { Anxiety Scale, and } \\
\text { Clinical Global } \\
\text { Impression for } 7 \text { of } 8 \\
\text { unipolar depressed } \\
\text { patients }\end{array}$ & $\begin{array}{l}\text { Direct effect on } \\
\text { disease (no } \\
\text { RCT) }\end{array}$ \\
\hline
\end{tabular}


Table 7. Cont

\begin{tabular}{|c|c|c|c|c|c|c|c|}
\hline Study & Disease & Subject & Treatment & Randomized & Subjects & Efficacy & Effect Role \\
\hline $\begin{array}{l}\text { Toniolo } \\
\text { et al. [252] }\end{array}$ & $\begin{array}{l}\text { Depressive } \\
\text { episode of } \\
\text { Bipolar Type } 1 \\
\text { and Type } 2\end{array}$ & Human & $\begin{array}{l}6 \mathrm{~g} / \mathrm{d} \text { creatine } \\
\text { for } 6 \text { weeks }\end{array}$ & Yes & 35 & $\begin{array}{l}\text { No significant } \\
\text { difference in } \\
\text { Montgomery-Åsberg } \\
\text { Depression Rating } \\
\text { Scale by intervention } \\
\text { but higher remission } \\
\text { rate in creatine } \\
\text { supplemented group }\end{array}$ & $\begin{array}{l}\text { Direct effect on } \\
\text { disease }\end{array}$ \\
\hline $\begin{array}{l}\text { Kondo } \\
\text { et al. [255] }\end{array}$ & $\begin{array}{l}\text { Adolescent } \\
\text { with SSRI } \\
\text { resistant major } \\
\text { depressive } \\
\text { disorder }\end{array}$ & Human & $\begin{array}{l}0 \text { g vs. } 2 \text { g vs. } 4 \\
\text { g vs. } 10 \mathrm{~g} \\
\text { creatine sup- } \\
\text { plementation } \\
\text { for } 8 \text { weeks }\end{array}$ & Yes & 34 & $\begin{array}{l}\text { Clinical depression } \\
\text { scores correlated } \\
\text { inversely with brain } \\
\text { phosphocreatine (PCR) } \\
\text { levels. PCR level } \\
\text { improved with higher } \\
\text { dose. }\end{array}$ & $\begin{array}{l}\text { Potential direct } \\
\text { effect on } \\
\text { disease }\end{array}$ \\
\hline
\end{tabular}

\section{Chronic Fatigue Syndrome, Post Viral Fatigue Syndrome, and Long COVID}

Fatigue is the most characteristic symptom of an energy deficit. There does not, however, exist a proper definition of the fatigue syndrome [259]. Fibromyalgia is a similar pathological entity closely related to CFS. Initially thought to be purely a psychological problem, linking fatigue to depression or other psychiatric diseases, newer research has been able to prove a metabolic dysfunction causing the symptoms $[99,260,261]$. Linking this clinical state with mitochondrial dysfunction was first able when lowered mitochondrial ATP levels were shown using MRS on patients with fatigue syndrome [262]. Later muscle biopsies and serum biomarkers have been able to show reduced mitochondrial biomarkers [263,264]. These markers have been Carnitine and CoQ10 [265]. On a mitochondrial level fatty acid metabolism was altered, electron transport chain was disrupted, there was a greater need in glucose concentrations and higher levels of lactate were shown [266]. Higher creatinine excretion via urine was shown to correlate positively with fatigue and pain severity. Being the end product of creatine, this urine marker could imply a higher turnover and depletion of the body's creatine storage [267]. More recent hypotheses state that these alterations have been caused by an activation of immune-inflammatory pathways due to viral infections (e.g., Epstein Barr, Q Fever, Ross River Infection) [268].

Long COVID is a persistent fatigue state after Sars-2-CoV-2 infection [269,270]. Interestingly, even asymptomatic patients exhibited raised biomarkers involved in inflammation and stress response [271]. Long COVID, Chronic Fatigue Syndrome, and Post Viral Fatigue Syndrome are believed to be the same entity $[248,272]$. Supplementation of guadinioacteic acid, a precursor of creatine, was able to attenuate several aspects of fatigue in fibromyalgia patients [273]. In combination of experimental findings as well as these first promising clinical outcomes, creatine might be an important key in the rehabilitation process of CFS and Long COVID patients [274]. Table 8 summarizes the available literature on the effects of the creatine precursor GAA on chronic fatigue and Post-COVID syndrome [274].

Table 8. Summary of literature on the effects of creatine precursors on chronic fatigue and PostCOVID syndrome.

\begin{tabular}{|c|c|c|c|c|c|c|c|}
\hline Study & Disease & Subject & Treatment & Randomized & Subjects & Efficacy & Effect Role \\
\hline $\begin{array}{l}\text { Ostojic et al. } \\
\text { [264] }\end{array}$ & $\begin{array}{l}\text { Chronic } \\
\text { Fatigue } \\
\text { syndrome }\end{array}$ & Human & $\begin{array}{l}2 \mathrm{~g}, 4 \mathrm{~g} \text { oral } \\
\text { Guanidi- } \\
\text { noacetic Acid } \\
\text { for } 3 \text { months } \\
\text { vs. placebo }\end{array}$ & Yes & 21 & $\begin{array}{l}\text { Higher muscle } \\
\text { creatine-phosphate } \\
\text { level and better } \\
\text { oxidative capacity. } \\
\text { However, no } \\
\text { significant } \\
\text { improvement of } \\
\text { fatigue symptoms }\end{array}$ & $\begin{array}{l}\text { Direct effect } \\
\text { on disease } \\
\text { related } \\
\text { metabolism }\end{array}$ \\
\hline
\end{tabular}




\section{Conclusions}

This review summarizes creatine's impact on mitochondrial function besides restoring ATP-storage. Creatine monohydrate is one of the best-known nutrient supplements mainly being used for improvement of athletic performance. However, there is growing evidence for a broader therapeutic spectrum of this nitrogen-amino-compound. Various healthpromoting effects on cell-metabolism after the intake of creatine have been shown. Its impact on mitochondrial integrity has become of special interest. Mitochondrial dysfunction has become a central pathological hallmark of non-communicable diseases. The supplementation of creatine monohydrate may have some synergistic effects in the treatment of CND. This seems to be directly related to its protective effects on mitochondria. Different from pharmaceutical products, the intake of creatine is safe age- and gender-independent with nearly no side-effects $[49,50]$. Although these findings are promising, much of the available data has been generated with in vitro or animal studies. Therefore, there is a need to conduct more clinical trials in humans to assess the potential therapeutic effects of creatine monohydrate supplementation on conditions influencing mitochondrial function.

Author Contributions: Conceptualization, R.P.M.; writing-original draft preparation, R.P.M.; writing — review and editing, R.P.M., J.-N.D., J.G., and R.B.K.; funding acquisition, R.P.M. All authors have read and agreed to the published version of the manuscript.

Funding: The APC of selected papers of this special issue are being funded by AlzChem, LLC. (Trostberg, Germany) who manufactures creatine monohydrate. The funders had no role in the writing of the manuscript, interpretation of the literature, or in the decision to publish the results.

Institutional Review Board Statement: Not applicable.

Informed Consent Statement: Not applicable.

Data Availability Statement: Not applicable.

Acknowledgments: The authors would like to thank all of the research participants, scholars, and funding agencies who have contributed to the research cited in this manuscript.

Conflicts of Interest: R.P.M. received financial support for presenting on creatine at industry sponsored scientific conferences. J.N.D. declares there is no financial and no non-financial conflict of interest. J.G. reports no conflict of interest. R.B.K. has conducted industry sponsored research on creatine, received financial support for presenting on creatine at industry sponsored scientific conferences, and has served as an expert witness on cases related to creatine. Additionally, he serves as Chair of the Scientific Advisory Board for AlzChem who sponsored this special issue.

\section{References}

1. Bonilla, D.A.; Kreider, R.B.; Stout, J.R.; Forero, D.A.; Kerksick, C.M.; Roberts, M.D.; Rawson, E.S. Metabolic Basis of Creatine in Health and Disease: A Bioinformatics-Assisted Review. Nutrients 2021, 13, 1238. [CrossRef]

2. Candow, D.G.; Forbes, S.C.; Chilibeck, P.D.; Cornish, S.M.; Antonio, J.; Kreider, R.B. Effectiveness of Creatine Supplementation on Aging Muscle and Bone: Focus on Falls Prevention and Inflammation. J. Clin. Med. 2019, 8, 488. [CrossRef]

3. Brosnan, M.E.; Brosnan, J.T. The role of dietary creatine. Amino Acids 2016, 48, 1785-1791. [CrossRef]

4. Harris, R. Creatine in health, medicine and sport: An introduction to a meeting held at Downing College, University of Cambridge, July 2010. Amino Acids 2011, 40, 1267. [CrossRef]

5. Harris, R.C.; Soderlund, K.; Hultman, E. Elevation of creatine in resting and exercised muscle of normal subjects by creatine supplementation. Clin. Sci. 1992, 83, 367-374. [CrossRef]

6. Kreider, R.B.; Stout, J.R. Creatine in Health and Disease. Nutrients 2021, 13, 447. [CrossRef]

7. Hultman, E.; Soderlund, K.; Timmons, J.A.; Cederblad, G.; Greenhaff, P.L. Muscle creatine loading in men. J. Appl. Physiol. 1996, 81, 232-237. [CrossRef]

8. Wallimann, T.; Tokarska-Schlattner, M.; Schlattner, U. The creatine kinase system and pleiotropic effects of creatine. Amino Acids 2011, 40, 1271-1296. [CrossRef]

9. Huertas, J.R.; Casuso, R.A.; Agustín, P.H.; Cogliati, S. Stay Fit, Stay Young: Mitochondria in Movement: The Role of Exercise in the New Mitochondrial Paradigm. Oxidative Med. Cell. Longev. 2019, 2019, e7058350. [CrossRef]

10. Negro, M.; Avanzato, I.; D’Antona, G. Chapter 2.7-Creatine in Skeletal Muscle Physiology. In Nonvitamin and Nonmineral Nutritional Supplements; Nabavi, S.M., Silva, A.S., Eds.; Academic Press: Cambridge, MA, USA, 2019; pp. 59-68. 
11. Nelson, A.G.; Arnall, D.A.; Kokkonen, J.; Day, R.; Evans, J. Muscle glycogen supercompensation is enhanced by prior creatine supplementation. Med. Sci. Sports Exerc. 2001, 33, 1096-1100. [CrossRef]

12. Tarnopolsky, M.A.; Parise, G. Direct measurement of high-energy phosphate compounds in patients with neuromuscular disease Muscle Nerve 1999, 22, 1228-1233. [CrossRef]

13. McKenna, M.J.; Morton, J.; Selig, S.E.; Snow, R.J. Creatine supplementation increases muscle total creatine but not maximal intermittent exercise performance. J. Appl. Physiol. 1999, 87, 2244-2252. [CrossRef]

14. Greenhaff, P.L.; Bodin, K.; Soderlund, K.; Hultman, E. Effect of oral creatine supplementation on skeletal muscle phosphocreatine resynthesis. Am. J. Physiol. 1994, 266, E725-E730. [CrossRef]

15. Greenwood, M.; Kreider, R.B.; Earnest, C.P.; Rasmussen, C.; Almada, A. Differences in creatine retention among three nutritional formulations of oral creatine supplements. J. Exerc. Physiol. Online 2003, 6, 37-43.

16. Choi, J.K.; Kustermann, E.; Dedeoglu, A.; Jenkins, B.G. Magnetic resonance spectroscopy of regional brain metabolite markers in FALS mice and the effects of dietary creatine supplementation. Eur. J. Neurosci. 2009, 30, 2143-2150. [CrossRef]

17. Lyoo, I.K.; Kong, S.W.; Sung, S.M.; Hirashima, F.; Parow, A.; Hennen, J.; Cohen, B.M.; Renshaw, P.F. Multinuclear magnetic resonance spectroscopy of high-energy phosphate metabolites in human brain following oral supplementation of creatinemonohydrate. Psychiatry Res. 2003, 123, 87-100. [CrossRef]

18. Roschel, H.; Gualano, B.; Ostojic, S.M.; Rawson, E.S. Creatine Supplementation and Brain Health. Nutrients 2021, 13, 586. [CrossRef]

19. Dolan, E.; Gualano, B.; Rawson, E.S. Beyond muscle: The effects of creatine supplementation on brain creatine, cognitive processing, and traumatic brain injury. Eur. J. Sport Sci. 2019, 19, 1-14. [CrossRef]

20. Gualano, B.; Rawson, E.S.; Candow, D.G.; Chilibeck, P.D. Creatine supplementation in the aging population: Effects on skeletal muscle, bone and brain. Amino Acids 2016, 48, 1793-1805. [CrossRef]

21. Rawson, E.S.; Venezia, A.C. Use of creatine in the elderly and evidence for effects on cognitive function in young and old. Amino Acids 2011, 40, 1349-1362. [CrossRef]

22. Cornish, S.M.; Chilibeck, P.D.; Burke, D.G. The effect of creatine monohydrate supplementation on sprint skating in ice-hockey players. J. Sports Med. Phys. Fitness 2006, 46, 90-98.

23. Dawson, B.; Vladich, T.; Blanksby, B.A. Effects of 4 weeks of creatine supplementation in junior swimmers on freestyle sprint and swim bench performance. J. Strength Cond. Res. 2002, 16, 485-490.

24. Grindstaff, P.D.; Kreider, R.; Bishop, R.; Wilson, M.; Wood, L.; Alexander, C.; Almada, A. Effects of creatine supplementation on repetitive sprint performance and body composition in competitive swimmers. Int. J. Sport Nutr. 1997, 7, 330-346. [CrossRef]

25. Juhasz, I.; Gyore, I.; Csende, Z.; Racz, L.; Tihanyi, J. Creatine supplementation improves the anaerobic performance of elite junior fin swimmers. Acta Physiol. Hung. 2009, 96, 325-336. [CrossRef]

26. Silva, A.J.; Machado Reis, V.; Guidetti, L.; Bessone Alves, F.; Mota, P.; Freitas, J.; Baldari, C. Effect of creatine on swimming velocity, body composition and hydrodynamic variables. J. Sports Med. Phys. Fitness 2007, 47, 58-64.

27. Kreider, R.B.; Ferreira, M.; Wilson, M.; Grindstaff, P.; Plisk, S.; Reinardy, J.; Cantler, E.; Almada, A.L. Effects of creatine supplementation on body composition, strength, and sprint performance. Med. Sci. Sports Exerc. 1998, 30, 73-82. [CrossRef]

28. Stone, M.H.; Sanborn, K.; Smith, L.L.; O’Bryant, H.S.; Hoke, T.; Utter, A.C.; Johnson, R.L.; Boros, R.; Hruby, J.; Pierce, K.C.; et al. Effects of in-season (5 weeks) creatine and pyruvate supplementation on anaerobic performance and body composition in American football players. Int. J. Sport Nutr. 1999, 9, 146-165. [CrossRef]

29. Bemben, M.G.; Bemben, D.A.; Loftiss, D.D.; Knehans, A.W. Creatine supplementation during resistance training in college football athletes. Med. Sci. Sports Exerc. 2001, 33, 1667-1673. [CrossRef]

30. Hoffman, J.; Ratamess, N.; Kang, J.; Mangine, G.; Faigenbaum, A.; Stout, J. Effect of creatine and beta-alanine supplementation on performance and endocrine responses in strength/power athletes. Int. J. Sport Nutr. Exerc. Metab. 2006, 16, 430-446. [CrossRef]

31. Chilibeck, P.D.; Magnus, C.; Anderson, M. Effect of in-season creatine supplementation on body composition and performance in rugby union football players. Appl. Physiol. Nutr. Metab. 2007, 32, 1052-1057. [CrossRef]

32. Claudino, J.G.; Mezencio, B.; Amaral, S.; Zanetti, V.; Benatti, F.; Roschel, H.; Gualano, B.; Amadio, A.C.; Serrao, J.C. Creatine monohydrate supplementation on lower-limb muscle power in Brazilian elite soccer players. J. Int. Soc. Sports Nutr. 2014, 11, 32. [CrossRef]

33. Kerksick, C.M.; Rasmussen, C.; Lancaster, S.; Starks, M.; Smith, P.; Melton, C.; Greenwood, M.; Almada, A.; Kreider, R. Impact of differing protein sources and a creatine containing nutritional formula after 12 weeks of resistance training. Nutrition 2007, 23, 647-656. [CrossRef]

34. Kerksick, C.M.; Wilborn, C.D.; Campbell, W.I.; Harvey, T.M.; Marcello, B.M.; Roberts, M.D.; Parker, A.G.; Byars, A.G.; Greenwood, L.D.; Almada, A.L.; et al. The effects of creatine monohydrate supplementation with and without D-pinitol on resistance training adaptations. J. Strength Cond. Res. 2009, 23, 2673-2682. [CrossRef]

35. Galvan, E.; Walker, D.K.; Simbo, S.Y.; Dalton, R.; Levers, K.; O'Connor, A.; Goodenough, C.; Barringer, N.D.; Greenwood, M.; Rasmussen, C.; et al. Acute and chronic safety and efficacy of dose dependent creatine nitrate supplementation and exercise performance. J. Int. Soc. Sports Nutr. 2016, 13, 12. [CrossRef]

36. Volek, J.S.; Kraemer, W.J.; Bush, J.A.; Boetes, M.; Incledon, T.; Clark, K.L.; Lynch, J.M. Creatine supplementation enhances muscular performance during high-intensity resistance exercise. J. Am. Diet. Assoc. 1997, 97, 765-770. [CrossRef] 
37. Volek, J.S.; Mazzetti, S.A.; Farquhar, W.B.; Barnes, B.R.; Gomez, A.L.; Kraemer, W.J. Physiological responses to short-term exercise in the heat after creatine loading. Med. Sci. Sports Exerc. 2001, 33, 1101-1108. [CrossRef]

38. Volek, J.S.; Ratamess, N.A.; Rubin, M.R.; Gomez, A.L.; French, D.N.; McGuigan, M.M.; Scheett, T.P.; Sharman, M.J.; Hakkinen, K.; Kraemer, W.J. The effects of creatine supplementation on muscular performance and body composition responses to short-term resistance training overreaching. Eur. J. Appl. Physiol. 2004, 91, 628-637. [CrossRef]

39. Buford, T.W.; Kreider, R.B.; Stout, J.R.; Greenwood, M.; Campbell, B.; Spano, M.; Ziegenfuss, T.; Lopez, H.; Landis, J.; Antonio, J. International Society of Sports Nutrition position stand: Creatine supplementation and exercise. J. Int. Soc. Sports Nutr. 2007, 4, 6. [CrossRef]

40. Kreider, R.B.; Wilborn, C.D.; Taylor, L.; Campbell, B.; Almada, A.L.; Collins, R.; Cooke, M.; Earnest, C.P.; Greenwood, M.; Kalman, D.S.; et al. ISSN exercise \& sport nutrition review: Research \& recommendations. J. Int. Soc. Sports Nutr. 2010, 7, 7. [CrossRef]

41. Branch, J.D. Effect of creatine supplementation on body composition and performance: A meta-analysis. Int. J. Sport Nutr. Exerc. Metab. 2003, 13, 198-226. [CrossRef]

42. Devries, M.C.; Phillips, S.M. Creatine supplementation during resistance training in older adults-a meta-analysis. Med. Sci. Sports Exerc. 2014, 46, 1194-1203. [CrossRef]

43. Lanhers, C.; Pereira, B.; Naughton, G.; Trousselard, M.; Lesage, F.X.; Dutheil, F. Creatine Supplementation and Lower Limb Strength Performance: A Systematic Review and Meta-Analyses. Sports Med. 2015, 45, 1285-1294. [CrossRef]

44. Wiroth, J.B.; Bermon, S.; Andrei, S.; Dalloz, E.; Hebuterne, X.; Dolisi, C. Effects of oral creatine supplementation on maximal pedalling performance in older adults. Eur. J. Appl. Physiol. 2001, 84, 533-539. [CrossRef]

45. McMorris, T.; Mielcarz, G.; Harris, R.C.; Swain, J.P.; Howard, A. Creatine supplementation and cognitive performance in elderly individuals. Neuropsychol. Dev. Cogn. B Aging Neuropsychol. Cogn. 2007, 14, 517-528. [CrossRef]

46. Rawson, E.S.; Clarkson, P.M. Acute creatine supplementation in older men. Int. J. Sports Med. 2000, 21, 71-75. [CrossRef]

47. Tarnopolsky, M.A. Potential benefits of creatine monohydrate supplementation in the elderly. Curr. Opin. Clin. Nutr. Metab. Care 2000, 3, 497-502. [CrossRef]

48. Aguiar, A.F.; Januario, R.S.; Junior, R.P.; Gerage, A.M.; Pina, F.L.; do Nascimento, M.A.; Padovani, C.R.; Cyrino, E.S. Long-term creatine supplementation improves muscular performance during resistance training in older women. Eur. J. Appl. Physiol. 2013, 113, 987-996. [CrossRef]

49. Kreider, R.B.; Kalman, D.S.; Antonio, J.; Ziegenfuss, T.N.; Wildman, R.; Collins, R.; Candow, D.G.; Kleiner, S.M.; Almada, A.L.; Lopez, H.L. International Society of Sports Nutrition position stand: Safety and efficacy of creatine supplementation in exercise, sport, and medicine. J. Int. Soc. Sports Nutr. 2017, 14, 18. [CrossRef]

50. Antonio, J.; Candow, D.G.; Forbes, S.C.; Gualano, B.; Jagim, A.R.; Kreider, R.B.; Rawson, E.S.; Smith-Ryan, A.E.; VanDusseldorp, T.A.; Willoughby, D.S.; et al. Common questions and misconceptions about creatine supplementation: What does the scientific evidence really show? J. Int. Soc. Sports Nutr. 2021, 18, 13. [CrossRef]

51. Brand, M.D.; Nicholls, D.G. Assessing mitochondrial dysfunction in cells. Biochem. J. 2011, 435, 297-312. [CrossRef]

52. Read, C.Y.; Calnan, R.J. Mitochondrial disease: Beyond etiology unknown. J. Pediatr. Nurs. 2000, 15, 232-241. [CrossRef]

53. Cohen, B.H.; Gold, D.R. Mitochondrial cytopathy in adults: What we know so far. Clev. Clin. J. Med. 2001, 68, 625-642. [CrossRef]

54. Giza, C.C.; Hovda, D.A. The Neurometabolic Cascade of Concussion. J. Athl. Train 2001, 36, 228-235. [CrossRef]

55. Dean, A.; Philip, J.; Arikan, G.; Opitz, B.; Sterr, A. Potential for use of creatine supplementation following mild traumatic brain injury. Concussion 2017, 2, CNC34. [CrossRef]

56. Gaetz, M. The neurophysiology of brain injury. Clin. Neurophysiol. 2004, 115, 4-18. [CrossRef]

57. Brooke, N.S.; Ouwerkerk, R.; Adams, C.B.; Radda, G.K.; Ledingham, J.G.; Rajagopalan, B. Phosphorus-31 magnetic resonance spectra reveal prolonged intracellular acidosis in the brain following subarachnoid hemorrhage. Proc. Natl. Acad. Sci. USA 1994, 91, 1903-1907. [CrossRef]

58. Abe, K.; Aoki, M.; Kawagoe, J.; Yoshida, T.; Hattori, A.; Kogure, K.; Itoyama, Y. Ischemic Delayed Neuronal Death. Stroke 1995, 26, 1478-1489. [CrossRef]

59. Ankarcrona, M.; Dypbukt, J.M.; Bonfoco, E.; Zhivotovsky, B.; Orrenius, S.; Lipton, S.A.; Nicotera, P. Glutamate-induced neuronal death: A succession of necrosis or apoptosis depending on mitochondrial function. Neuron 1995, 15, 961-973. [CrossRef]

60. Fiskum, G.; Murphy, A.N.; Beal, M.F. Mitochondria in Neurodegeneration: Acute Ischemia and Chronic Neurodegenerative Diseases. J. Cereb. Blood Flow Metab. 1999, 19, 351-369. [CrossRef]

61. Schinder, A.F.; Olson, E.C.; Spitzer, N.C.; Montal, M. Mitochondrial Dysfunction Is a Primary Event in Glutamate Neurotoxicity. J. Neurosci. 1996, 16, 6125-6133. [CrossRef]

62. Béard, E.; Braissant, O. Synthesis and transport of creatine in the CNS: Importance for cerebral functions. J. Neurochem. 2010, 115, 297-313. [CrossRef]

63. Rabinowitz, A.R.; Li, X.; Levin, H.S. Sport and nonsport etiologies of mild traumatic brain injury: Similarities and differences. Annu. Rev. Psychol. 2014, 65, 301-331. [CrossRef]

64. Signoretti, S.; Lazzarino, G.; Tavazzi, B.; Vagnozzi, R. The pathophysiology of concussion. PM R 2011, 3, S359-S368. [CrossRef]

65. Andres, R.H.; Ducray, A.D.; Schlattner, U.; Wallimann, T.; Widmer, H.R. Functions and effects of creatine in the central nervous system. Brain Res. Bull. 2008, 76, 329-343. [CrossRef]

66. Gualano, B.; Roschel, H.; Lancha, A.H.; Brightbill, C.E.; Rawson, E.S. In sickness and in health: The widespread application of creatine supplementation. Amino Acids 2012, 43, 519-529. [CrossRef] 
67. Rae, C.D.; Bröer, S. Creatine as a booster for human brain function. How might it work? Neurochem. Int. 2015, 89, 249-259. [CrossRef]

68. Perasso, L.; Spallarossa, P.; Gandolfo, C.; Ruggeri, P.; Balestrino, M. Therapeutic Use of Creatine in Brain or Heart Ischemia: Available Data and Future Perspectives. Med. Res. Rev. 2013, 33, 336-363. [CrossRef]

69. O'Gorman, E.; Beutner, G.; Dolder, M.; Koretsky, A.P.; Brdiczka, D.; Wallimann, T. The role of creatine kinase in inhibition of mitochondrial permeability transition. FEBS Lett. 1997, 414, 253-257. [CrossRef]

70. Meyer, L.E.; Machado, L.B.; Santiago, A.P.; Da-Silva, W.S.; De Felice, F.G.; Holub, O.; Oliveira, M.F.; Galina, A. Mitochondrial creatine kinase activity prevents reactive oxygen species generation: Antioxidant role of mitochondrial kinase-dependent ADP re-cycling activity. J. Biol. Chem. 2006, 281, 37361-37371. [CrossRef]

71. Sakellaris, G.; Kotsiou, M.; Tamiolaki, M.; Kalostos, G.; Tsapaki, E.; Spanaki, M.; Spilioti, M.; Charissis, G.; Evangeliou, A. Prevention of complications related to traumatic brain injury in children and adolescents with creatine administration: An open label randomized pilot study. J. Trauma 2006, 61, 322-329. [CrossRef]

72. Sakellaris, G.; Nasis, G.; Kotsiou, M.; Tamiolaki, M.; Charissis, G.; Evangeliou, A. Prevention of traumatic headache, dizziness and fatigue with creatine administration. A pilot study. Acta Paediatr. 2008, 97, 31-34. [CrossRef]

73. Sosa, V.; Moliné, T.; Somoza, R.; Paciucci, R.; Kondoh, H.; Lleonart, M.E. Oxidative stress and cancer: An overview. Ageing Res. Rev. 2013, 12, 376-390. [CrossRef]

74. Nicolson, G.L.; Ferreira, G.; Settineri, R.; Ellithorpe, R.R.; Breeding, P.; Ash, M.E. Mitochondrial Dysfunction and Chronic Disease: Treatment with Membrane Lipid Replacement and Other Natural Supplements. In Mitochondrial Biology and Experimental Therapeutics; Oliveira, P.J., Ed.; Springer International Publishing: Berlin/Heidelberg, Germany, 2018; pp. 499-522.

75. Newell, C.; Leduc-Pessah, H.; Khan, A.; Shearer, J. Mitochondrial Dysfunction in Chronic Disease. In The Routledge Handbook on Biochemistry of Exercise; Routledge: Abingdon, UK, 2020.

76. Victor, M.V.; Rocha, M.; Herance, R.; Hernandez-Mijares, A. Oxidative Stress and Mitochondrial Dysfunction in Type 2 Diabetes. Curr. Pharm. Des. 2011, 17, 3947-3958. [CrossRef]

77. Picard, M.; Turnbull, D.M. Linking the Metabolic State and Mitochondrial DNA in Chronic Disease, Health, and Aging. Diabetes 2013, 62, 672-678. [CrossRef]

78. Pieczenik, S.R.; Neustadt, J. Mitochondrial dysfunction and molecular pathways of disease. Exp. Mol. Pathol. 2007, 83, 84-92. [CrossRef]

79. Madamanchi, N.R.; Runge, M.S. Mitochondrial Dysfunction in Atherosclerosis. Circ. Res. 2007, 100, 460-473. [CrossRef]

80. Galvan, D.L.; Green, N.H.; Danesh, F.R. The hallmarks of mitochondrial dysfunction in chronic kidney disease. Kidney Int. 2017, 92, 1051-1057. [CrossRef]

81. Cloonan, S.M.; Kim, K.; Esteves, P.; Trian, T.; Barnes, P.J. Mitochondrial dysfunction in lung ageing and disease. Eur. Respir. Rev. 2020, 29, 157. [CrossRef]

82. Wei, P.Z.; Szeto, C.C. Mitochondrial dysfunction in diabetic kidney disease. Clin. Chim. Acta 2019, 496, 108-116. [CrossRef]

83. Mansouri, A.; Gattolliat, C.-H.; Asselah, T. Mitochondrial Dysfunction and Signaling in Chronic Liver Diseases. Gastroenterology 2018, 155, 629-647. [CrossRef]

84. Fang, T.; Wang, M.; Xiao, H.; Wei, X. Mitochondrial dysfunction and chronic lung disease. Cell Biol. Toxicol. 2019, 35, 493-502. [CrossRef] [PubMed]

85. López-Armada, M.J.; Riveiro-Naveira, R.R.; Vaamonde-García, C.; Valcárcel-Ares, M.N. Mitochondrial dysfunction and the inflammatory response. Mitochondrion 2013, 13, 106-118. [CrossRef] [PubMed]

86. Castellani, R.; Hirai, K.; Aliev, G.; Drew, K.L.; Nunomura, A.; Takeda, A.; Cash, A.D.; Obrenovich, M.E.; Perry, G.; Smith, M.A Role of mitochondrial dysfunction in Alzheimer's disease. J. Neurosci. Res. 2002, 70, 357-360. [CrossRef] [PubMed]

87. Sorrentino, V.; Menzies, K.J.; Auwerx, J. Repairing Mitochondrial Dysfunction in Disease. Annu. Rev. Pharmacol. Toxicol. 2018, 58, 353-389. [CrossRef]

88. Abrigo, J.; Simon, F.; Cabrera, D.; Vilos, C.; Cabello-Verrugio, C. Mitochondrial Dysfunction in Skeletal Muscle Pathologies. Curr. Protein Pept. Sci. 2019, 20, 536-546. [CrossRef] [PubMed]

89. Prakash, Y.S.; Pabelick, C.M.; Sieck, G.C. Mitochondrial Dysfunction in Airway Disease. Chest 2017, 152, 618-626. [CrossRef]

90. Diaz-Vegas, A.; Sanchez-Aguilera, P.; Krycer, J.R.; Morales, P.E.; Monsalves-Alvarez, M.; Cifuentes, M.; Rothermel, B.A.; Lavandero, S. Is Mitochondrial Dysfunction a Common Root of Noncommunicable Chronic Diseases? Endocr. Rev. 2020, 41, 491-517. [CrossRef]

91. Novak, E.A.; Mollen, K.P. Mitochondrial dysfunction in inflammatory bowel disease. Front. Cell Dev. Biol. 2015, 3, 62. [CrossRef]

92. Ballinger, S.W. Mitochondrial dysfunction in cardiovascular disease. Free Radic. Biol. Med. 2005, 38, 1278-1295. [CrossRef]

93. Rosca, M.G.; Hoppel, C.L. Mitochondrial dysfunction in heart failure. Heart Fail. Rev. 2013, 18, 607-622. [CrossRef]

94. Chistiakov, D.A.; Shkurat, T.P.; Melnichenko, A.A.; Grechko, A.V.; Orekhov, A.N. The role of mitochondrial dysfunction in cardiovascular disease: A brief review. Ann. Med. 2018, 50, 121-127. [CrossRef] [PubMed]

95. Li, X.; Zhang, W.; Cao, Q.; Wang, Z.; Zhao, M.; Xu, L.; Zhuang, Q. Mitochondrial dysfunction in fibrotic diseases. Cell Death Discov. 2020, 6, 1-14. [CrossRef] [PubMed]

96. Johri, A.; Beal, M.F. Mitochondrial Dysfunction in Neurodegenerative Diseases. J. Pharmacol. Exp. Ther. 2012, 342, 619-630. [CrossRef] [PubMed] 
97. Barot, M.; Gokulgandhi, M.R.; Mitra, A.K. Mitochondrial Dysfunction in Retinal Diseases. Curr. Eye Res. 2011, 36, 1069-1077. [CrossRef] [PubMed]

98. Hu, F.; Liu, F. Mitochondrial stress: A bridge between mitochondrial dysfunction and metabolic diseases? Cell. Signal. 2011, 23, 1528-1533. [CrossRef] [PubMed]

99. Myhill, S.; Booth, N.E.; McLaren-Howard, J. Chronic fatigue syndrome and mitochondrial dysfunction. Int. J. Clin. Exp. Med. 2009, 2, 1-16.

100. Haas, R.H. Mitochondrial Dysfunction in Aging and Diseases of Aging. Biology 2019, 8, 48. [CrossRef]

101. Kemp, G.J. Mitochondrial dysfunction in chronic ischemia and peripheral vascular disease. Mitochondrion 2004, 4, 629-640. [CrossRef]

102. Liberti, M.V.; Locasale, J.W. The Warburg Effect: How Does it Benefit Cancer Cells? Trends Biochem. Sci. 2016, 41, 211-218. [CrossRef]

103. Vander Heiden, M.G.; Cantley, L.C.; Thompson, C.B. Understanding the Warburg Effect: The Metabolic Requirements of Cell Proliferation. Science 2009, 324, 1029-1033. [CrossRef]

104. Zapelini, P.H.; Rezin, G.T.; Cardoso, M.R.; Ritter, C.; Klamt, F.; Moreira, J.C.F.; Streck, E.L.; Dal-Pizzol, F. Antioxidant treatment reverses mitochondrial dysfunction in a sepsis animal model. Mitochondrion 2008, 8, 211-218. [CrossRef] [PubMed]

105. Molnár, A.G.; Kun, S.; Sélley, E.; Kertész, M.; Szélig, L.; Csontos, C.; Böddi, K.; Bogár, L.; Miseta, A.; Wittmann, I. Role of Tyrosine Isomers in Acute and Chronic Diseases Leading to Oxidative Stress-A Review. Curr. Med. Chem. 2016, 23, 667-685. [CrossRef] [PubMed]

106. Ortiz, G.G.; Pacheco Moisés, F.P.; Mireles-Ramírez, M.; Flores-Alvarado, L.J.; González-Usigli, H.; Sánchez-González, V.J.; Sánchez-López, A.L.; Sánchez-Romero, L.; Díaz-Barba, E.I.; Santoscoy-Gutiérrez, J.F.; et al. Chapter One-Oxidative Stress: Love and Hate History in Central Nervous System. In Advances in Protein Chemistry and Structural Biology; Stress and Inflammation in Disorders; Donev, R., Ed.; Academic Press: Cambridge, MA, USA, 2017; Volume 108, pp. 1-31.

107. Incalza, M.A.; D'Oria, R.; Natalicchio, A.; Perrini, S.; Laviola, L.; Giorgino, F. Oxidative stress and reactive oxygen species in endothelial dysfunction associated with cardiovascular and metabolic diseases. Vasc. Pharmacol. 2018, 100, 1-19. [CrossRef] [PubMed]

108. Pall, M.L.; Levine, S. Nrf2, a master regulator of detoxification and also antioxidant, anti-inflammatory and other cytoprotective mechanisms, is raised by health promoting factors. Sheng Li Xue Bao 2015, 67, 1-18.

109. Moldogazieva, N.T.; Mokhosoev, I.M.; Mel'nikova, T.I.; Porozov, Y.B.; Terentiev, A.A. Oxidative Stress and Advanced Lipoxidation and Glycation End Products (ALEs and AGEs) in Aging and Age-Related Diseases. Oxidative Med. Cell. Longev. 2019, 2019, e3085756. [CrossRef] [PubMed]

110. Bangsbo, J. Energy demands in competitive soccer. J. Sports Sci. 1994, 12, S5-S12. [CrossRef]

111. Adeva, M.M.; Souto, G.; Blanco, N.; Donapetry, C. Ammonium metabolism in humans. Metabolism 2012, 61, 1495-1511. [CrossRef]

112. Mutch, B.J.; Banister, E.W. Ammonia metabolism in exercise and fatigue: A review. Med. Sci. Sports Exerc. 1983, 15, 41-50. [CrossRef]

113. Srinivasan, S.; Guha, M.; Kashina, A.; Avadhani, N.G. Mitochondrial Dysfunction and Mitochondrial Dynamics-The Cancer Connection. Biochim. Biophys. Acta 2017, 1858, 602-614. [CrossRef]

114. Stork, C.; Renshaw, P.F. Mitochondrial dysfunction in bipolar disorder: Evidence from magnetic resonance spectroscopy research. Mol. Psychiatry 2005, 10, 900-919. [CrossRef]

115. Devic, S. Warburg Effect-a Consequence or the Cause of Carcinogenesis? J. Cancer 2016, 7, 817-822. [CrossRef] [PubMed]

116. Rani, V.; Deep, G.; Singh, R.K.; Palle, K.; Yadav, U.C.S. Oxidative stress and metabolic disorders: Pathogenesis and therapeutic strategies. Life Sci. 2016, 148, 183-193. [CrossRef] [PubMed]

117. Stepien, K.M.; Heaton, R.; Rankin, S.; Murphy, A.; Bentley, J.; Sexton, D.; Hargreaves, I.P. Evidence of Oxidative Stress and Secondary Mitochondrial Dysfunction in Metabolic and Non-Metabolic Disorders. J. Clin. Med. 2017, 6, 71. [CrossRef] [PubMed]

118. Mlynárik, V. Introduction to nuclear magnetic resonance. Anal. Biochem. 2017, 529, 4-9. [CrossRef] [PubMed]

119. Prost, R.W. Magnetic resonance spectroscopy. Med. Phys. 2008, 35, 4530-4544. [CrossRef] [PubMed]

120. Henning, A. Proton and multinuclear magnetic resonance spectroscopy in the human brain at ultra-high field strength: A review. Neuroimage 2018, 168, 181-198. [CrossRef]

121. Porter, D.A.; Smith, M.A. Magnetic resonance spectroscopy in vivo. J. Biomed. Eng. 1988, 10, 562-568. [CrossRef]

122. Bertolino, A.; Frye, M.; Callicott, J.H.; Mattay, V.S.; Rakow, R.; Shelton-Repella, J.; Post, R.; Weinberger, D.R. Neuronal pathology in the hippocampal area of patients with bipolar disorder: A study with proton magnetic resonance spectroscopic imaging. Biol. Psychiatry 2003, 53, 906-913. [CrossRef]

123. Dager, S.R.; Friedman, S.D.; Parow, A.; Demopulos, C.; Stoll, A.L.; Lyoo, I.K.; Dunner, D.L.; Renshaw, P.F. Brain Metabolic Alterations in Medication-Free Patients with BipolarDisorder. Arch. Gen. Psychiatry 2004, 61, 450-458. [CrossRef]

124. Kato, T.; Takahashi, S.; Shioiri, T.; Inubushi, T. Brain phosphorous metabolism in depressive disorders detected by phosphorus-31 magnetic resonance spectroscopy. J. Affect. Disord. 1992, 26, 223-230. [CrossRef]

125. Kato, T.; Shioiri, T.; Murashita, J.; Hamakawa, H.; Takahashi, Y.; Inubushi, T.; Takahashi, S. Lateralized abnormality of high energy phosphate metabolism in the frontal lobes of patients with bipolar disorder detected by phase-encoded 31P-MRS. Psychol. Med. 1995, 25, 557-566. [CrossRef] [PubMed] 
126. Riesberg, L.A.; Weed, S.A.; McDonald, T.L.; Eckerson, J.M.; Drescher, K.M. Beyond muscles: The untapped potential of creatine. Int. Immunopharmacol. 2016, 37, 31-42. [CrossRef] [PubMed]

127. Wyss, M.; Schulze, A. Health implications of creatine: Can oral creatine supplementation protect against neurological and atherosclerotic disease? Neuroscience 2002, 112, 243-260. [CrossRef]

128. Guimarães-Ferreira, L.; Pinheiro, C.H.J.; Gerlinger-Romero, F.; Vitzel, K.F.; Nachbar, R.T.; Curi, R.; Nunes, M.T. Short-term creatine supplementation decreases reactive oxygen species content with no changes in expression and activity of antioxidant enzymes in skeletal muscle. Eur. J. Appl. Physiol. 2012, 112, 3905-3911. [CrossRef]

129. Hunter, D.J.; Reddy, K.S. Noncommunicable Diseases. N. Engl. J. Med. 2013, 369, 1336-1343. [CrossRef]

130. Peña-Oyarzun, D.; Bravo-Sagua, R.; Diaz-Vega, A.; Aleman, L.; Chiong, M.; Garcia, L.; Bambs, C.; Troncoso, R.; Cifuentes, M.; Morselli, E.; et al. Autophagy and oxidative stress in non-communicable diseases: A matter of the inflammatory state? Free Radic. Biol. Med. 2018, 124, 61-78. [CrossRef]

131. Lozano, R.; Naghavi, M.; Foreman, K.; Lim, S.; Shibuya, K.; Aboyans, V.; Abraham, J.; Adair, T.; Aggarwal, R.; Ahn, S.Y.; et al Global and regional mortality from 235 causes of death for 20 age groups in 1990 and 2010: A systematic analysis for the Global Burden of Disease Study 2010. Lancet 2012, 380, 2095-2128. [CrossRef]

132. Murray, C.J.L.; Lopez, A.D. Measuring the Global Burden of Disease. N. Engl. J. Med. 2013, 369, 448-457. [CrossRef]

133. World Health Organization. Noncommunicable Diseases: Progress Monitor 2020; World Health Organization: Geneva, Switzerland, 2020.

134. Yu, E.P.K.; Reinhold, J.; Yu, H.; Starks, L.; Uryga, A.K.; Foote, K.; Finigan, A.; Figg, N.; Pung, Y.-F.; Logan, A.; et al. Mitochondrial Respiration Is Reduced in Atherosclerosis, Promoting Necrotic Core Formation and Reducing Relative Fibrous Cap Thickness. Arterioscler. Thromb. Vasc. Biol. 2017, 37, 2322-2332. [CrossRef]

135. Shimizu, S.; Ishibashi, M.; Kumagai, S.; Wajima, T.; Hiroi, T.; Kurihara, T.; Ishii, M.; Kiuchi, Y. Decreased cardiac mitochondrial tetrahydrobiopterin in a rat model of pressure overload. Int. J. Mol. Med. 2013, 31, 589-596. [CrossRef]

136. Tang, Y.; Mi, C.; Liu, J.; Gao, F.; Long, J. Compromised mitochondrial remodeling in compensatory hypertrophied myocardium of spontaneously hypertensive rat. Cardiovasc. Pathol. 2014, 23, 101-106. [CrossRef] [PubMed]

137. Walther, T.; Tschöpe, C.; Sterner-Kock, A.; Westermann, D.; Heringer-Walther, S.; Riad, A.; Nikolic, A.; Wang, Y.; Ebermann, L.; Siems, W.-E.; et al. Accelerated Mitochondrial Adenosine Diphosphate/Adenosine Triphosphate Transport Improves Hypertension-Induced Heart Disease. Circulation 2007, 115, 333-344. [CrossRef] [PubMed]

138. Yu, T.; Robotham, J.L.; Yoon, Y. Increased production of reactive oxygen species in hyperglycemic conditions requires dynamic change of mitochondrial morphology. Proc. Natl. Acad. Sci. USA 2006, 103, 2653-2658. [CrossRef] [PubMed]

139. Tormos, K.V.; Anso, E.; Hamanaka, R.B.; Eisenbart, J.; Joseph, J.; Kalyanaraman, B.; Chandel, N.S. Mitochondrial Complex III ROS Regulate Adipocyte Differentiation. Cell Metab. 2011, 14, 537-544. [CrossRef]

140. Teodoro, J.S.; Rolo, A.P.; Duarte, F.V.; Simões, A.M.; Palmeira, C.M. Differential alterations in mitochondrial function induced by a choline-deficient diet: Understanding fatty liver disease progression. Mitochondrion 2008, 8, 367-376. [CrossRef]

141. Galloway, C.A.; Lee, H.; Brookes, P.S.; Yoon, Y. Decreasing mitochondrial fission alleviates hepatic steatosis in a murine model of nonalcoholic fatty liver disease. Am. J. Physiol. Gastrointest. Liver Physiol. 2014, 307, G632-G641. [CrossRef]

142. Tubbs, E.; Chanon, S.; Robert, M.; Bendridi, N.; Bidaux, G.; Chauvin, M.-A.; Ji-Cao, J.; Durand, C.; Gauvrit-Ramette, D.; Vidal, H.; et al. Disruption of Mitochondria-Associated Endoplasmic Reticulum Membrane (MAM) Integrity Contributes to Muscle Insulin Resistance in Mice and Humans. Diabetes 2018, 67, 636-650. [CrossRef]

143. Fazakerley, D.J.; Minard, A.Y.; Krycer, J.R.; Thomas, K.C.; Stöckli, J.; Harney, D.J.; Burchfield, J.G.; Maghzal, G.J.; Caldwell, S.T.; Hartley, R.C.; et al. Mitochondrial oxidative stress causes insulin resistance without disrupting oxidative phosphorylation. J. Biol. Chem. 2018, 293, 7315-7328. [CrossRef]

144. Anderson, E.J.; Lustig, M.E.; Boyle, K.E.; Woodlief, T.L.; Kane, D.A.; Lin, C.-T.; Price, J.W.; Kang, L.; Rabinovitch, P.S.; Szeto, H.H.; et al. Mitochondrial $\mathrm{H}_{2} \mathrm{O}_{2}$ emission and cellular redox state link excess fat intake to insulin resistance in both rodents and humans. J. Clin. Investig. 2009, 119, 573-581. [CrossRef]

145. Gutiérrez, T.; Parra, V.; Troncoso, R.; Pennanen, C.; Contreras-Ferrat, A.; Vasquez-Trincado, C.; Morales, P.E.; Lopez-Crisosto, C.; Sotomayor-Flores, C.; Chiong, M.; et al. Alteration in mitochondrial Ca2 ${ }^{+}$uptake disrupts insulin signaling in hypertrophic cardiomyocytes. Cell Commun. Signal. 2014, 12, 68. [CrossRef]

146. Tubbs, E.; Theurey, P.; Vial, G.; Bendridi, N.; Bravard, A.; Chauvin, M.-A.; Ji-Cao, J.; Zoulim, F.; Bartosch, B.; Ovize, M.; et al Mitochondria-Associated Endoplasmic Reticulum Membrane (MAM) Integrity Is Required for Insulin Signaling and Is Implicated in Hepatic Insulin Resistance. Diabetes 2014, 63, 3279-3294. [CrossRef] [PubMed]

147. Zhang, Z.; Wakabayashi, N.; Wakabayashi, J.; Tamura, Y.; Song, W.-J.; Sereda, S.; Clerc, P.; Polster, B.M.; Aja, S.M.; Pletnikov, M.V.; et al. The dynamin-related GTPase Opa1 is required for glucose-stimulated ATP production in pancreatic beta cells. Mol. Biol. Cell 2011, 22, 2235-2245. [CrossRef] [PubMed]

148. Reinhardt, F.; Schultz, J.; Waterstradt, R.; Baltrusch, S. Drp1 guarding of the mitochondrial network is important for glucosestimulated insulin secretion in pancreatic beta cells. Biochem. Biophys. Res. Commun. 2016, 474, 646-651. [CrossRef] [PubMed]

149. Anello, M.; Lupi, R.; Spampinato, D.; Piro, S.; Masini, M.; Boggi, U.; Del Prato, S.; Rabuazzo, A.M.; Purrello, F.; Marchetti, P. Functional and morphological alterations of mitochondria in pancreatic beta cells from type 2 diabetic patients. Diabetologia 2005, 48, 282-289. [CrossRef] 
150. Scheuermann-Freestone, M.; Madsen, P.L.; Manners, D.; Blamire, A.M.; Buckingham, R.E.; Styles, P.; Radda, G.K.; Neubauer, S.; Clarke, K. Abnormal cardiac and skeletal muscle energy metabolism in patients with type 2 diabetes. Circulation 2003, 107, 3040-3046. [CrossRef]

151. Rider, O.J.; Francis, J.M.; Ali, M.K.; Holloway, C.; Pegg, T.; Robson, M.D.; Tyler, D.; Byrne, J.; Clarke, K.; Neubauer, S. Effects of catecholamine stress on diastolic function and myocardial energetics in obesity. Circulation 2012, 125, 1511-1519. [CrossRef]

152. Lamb, H.J.; Beyerbacht, H.P.; Van der Laarse, A.; Stoel, B.C.; Doornbos, J.; Van der Wall, E.E.; De Roos, A. Diastolic dysfunction in hypertensive heart disease is associated with altered myocardial metabolism. Circulation 1999, 99, 2261-2267. [CrossRef]

153. Guescini, M.; Tiano, L.; Genova, M.L.; Polidori, E.; Silvestri, S.; Orlando, P.; Fimognari, C.; Calcabrini, C.; Stocchi, V.; Sestili, P. The Combination of Physical Exercise with Muscle-Directed Antioxidants to Counteract Sarcopenia: A Biomedical Rationale for Pleiotropic Treatment with Creatine and Coenzyme Q10. Oxidative Med. Cell. Longev. 2017, 2017, e7083049. [CrossRef]

154. Alves, C.R.R.; Filho, C.A.A.M.; Benatti, F.B.; Brucki, S.; Pereira, R.M.R.; Pinto, A.L.d.S.; Lima, F.R.; Roschel, H.; Gualano, B Creatine Supplementation Associated or Not with Strength Training upon Emotional and Cognitive Measures in Older Women: A Randomized Double-Blind Study. PLoS ONE 2013, 8, e76301. [CrossRef]

155. Candow, D.G.; Forbes, S.C.; Chilibeck, P.D.; Cornish, S.M.; Antonio, J.; Kreider, R.B. Variables Influencing the Effectiveness of Creatine Supplementation as a Therapeutic Intervention for Sarcopenia. Front. Nutr. 2019, 6, 124. [CrossRef]

156. Gualano, B.; Macedo, A.R.; Alves, C.R.; Roschel, H.; Benatti, F.B.; Takayama, L.; De Sa Pinto, A.L.; Lima, F.R.; Pereira, R.M Creatine supplementation and resistance training in vulnerable older women: A randomized double-blind placebo-controlled clinical trial. Exp. Gerontol. 2014, 53, 7-15. [CrossRef] [PubMed]

157. Lobo, D.M.; Tritto, A.C.; Da Silva, L.R.; De Oliveira, P.B.; Benatti, F.B.; Roschel, H.; Nieß, B.; Gualano, B.; Pereira, R.M.R. Effects of long-term low-dose dietary creatine supplementation in older women. Exp. Gerontol. 2015, 70, 97-104. [CrossRef] [PubMed]

158. Pinto, C.L.; Botelho, P.B.; Carneiro, J.A.; Mota, J.F. Impact of creatine supplementation in combination with resistance training on lean mass in the elderly. J. Cach. Sarc. Muscle 2016, 7, 413-421. [CrossRef] [PubMed]

159. Gualano, B.; Artioli, G.G.; Poortmans, J.R.; Lancha Junior, A.H. Exploring the therapeutic role of creatine supplementation. Amino Acids 2010, 38, 31-44. [CrossRef]

160. Candow, D.G.; Vogt, E.; Johannsmeyer, S.; Forbes, S.C.; Farthing, J.P. Strategic creatine supplementation and resistance training in healthy older adults. Appl. Physiol. Nutr. Metab. 2015, 40, 689-694. [CrossRef]

161. De Sousa, M.V.; Da Silva Soares, D.B.; Caraça, E.R.; Cardoso, R. Dietary protein and exercise for preservation of lean mass and perspectives on type 2 diabetes prevention. Exp. Biol. Med. 2019, 244, 992-1004. [CrossRef]

162. Barney, B.; Beck, G.R. Nutrition Interventions in Heart Failure. In Manual of Heart Failure Management; Bisognano, J.D., Earley, M.B., Baker, M.L., Eds.; Springer: Berlin/Heidelberg, Germany, 2009; pp. 207-217.

163. Solis, M.Y.; Artioli, G.G.; Gualano, B. Potential of Creatine in Glucose Management and Diabetes. Nutrients 2021, 13, 570. [CrossRef]

164. Gualano, B.; De Salles Painneli, V.; Roschel, H.; Artioli, G.G.; Neves, M.; De Sá Pinto, A.L.; Da Silva, M.E.R.; Cunha, M.R.; Otaduy, M.C.G.; Leite, C.D.C.; et al. Creatine in type 2 diabetes: A randomized, double-blind, placebo-controlled trial. Med. Sci. Sports Exerc. 2011, 43, 770-778. [CrossRef]

165. Earnest, C.P.; Almada, A.L.; Mitchell, T.L. High-performance capillary electrophoresis-pure creatine monohydrate reduces blood lipids in men and women. Clin. Sci. 1996, 91, 113-118. [CrossRef]

166. Deminice, R.; De Castro, G.S.F.; Francisco, L.V.; Da Silva, L.E.C.M.; Cardoso, J.F.R.; Frajacomo, F.T.T.; Teodoro, B.G.; Dos Reis Silveira, L.; Jordao, A.A. Creatine supplementation prevents fatty liver in rats fed choline-deficient diet: A burden of one-carbon and fatty acid metabolism. J. Nutr. Biochem. 2015, 26, 391-397. [CrossRef]

167. Gupta, A.; Akki, A.; Wang, Y.; Leppo, M.K.; Chacko, V.P.; Foster, D.B.; Caceres, V.; Shi, S.; Kirk, J.A.; Su, J.; et al. Creatine kinase-mediated improvement of function in failing mouse hearts provides causal evidence the failing heart is energy starved. $J$. Clin. Investig. 2012, 122, 291-302. [CrossRef] [PubMed]

168. Wallis, J.; Lygate, C.A.; Fischer, A.; ten Hove, M.; Schneider, J.E.; Sebag-Montefiore, L.; Dawson, D.; Hulbert, K.; Zhang, W.; Zhang, M.H.; et al. Supranormal Myocardial Creatine and Phosphocreatine Concentrations Lead to Cardiac Hypertrophy and Heart Failure. Circulation 2005, 112, 3131-3139. [CrossRef] [PubMed]

169. Nascimben, L.; Ingwall, J.S.; Pauletto, P.; Friedrich, J.; Gwathmey, J.K.; Saks, V.; Pessina, A.C.; Allen, P.d. Creatine Kinase System in Failing and Nonfailing Human Myocardium. Circulation 1996, 94, 1894-1901. [CrossRef] [PubMed]

170. Neubauer, S. The Failing Heart-An Engine Out of Fuel. N. Engl. J. Med. 2007, 356, 1140-1151. [CrossRef] [PubMed]

171. Shen, W.; Spindler, M.; Higgins, M.A.; Jin, N.; Gill, R.M.; Bloem, L.J.; Ryan, T.P.; Ingwall, J.S. The fall in creatine levels and creatine kinase isozyme changes in the failing heart are reversible: Complex post-transcriptional regulation of the components of the CK system. J. Mol. Cell. Cardiol. 2005, 39, 537-544. [CrossRef] [PubMed]

172. Lygate, C.A.; Fischer, A.; Sebag-Montefiore, L.; Wallis, J.; ten Hove, M.; Neubauer, S. The creatine kinase energy transport system in the failing mouse heart. J. Mol. Cell. Cardiol. 2007, 42, 1129-1136. [CrossRef]

173. Liao, R.; Nascimben, L.; Friedrich, J.; Gwathmey, J.K.; Ingwall, J.S. Decreased Energy Reserve in an Animal Model of Dilated Cardiomyopathy. Circ. Res. 1996, 78, 893-902. [CrossRef]

174. Zervou, S.; Whittington, H.J.; Russell, A.J.; Lygate, C.A. Augmentation of Creatine in the Heart. Mini Rev. Med. Chem. 2016, 16, 19-28. [CrossRef] 
175. Neubauer, S.; Krahe, T.; Schindler, R.; Horn, M.; Hillenbrand, H.; Entzeroth, C.; Mader, H.; Kromer, E.P.; Riegger, G.A.; Lackner, K. 31P magnetic resonance spectroscopy in dilated cardiomyopathy and coronary artery disease. Altered cardiac high-energy phosphate metabolism in heart failure. Circulation 1992, 86, 1810-1818. [CrossRef]

176. Neubauer, S.; Horn, M.; Pabst, T.; Gödde, M.; Lübke, D.; Jilling, B.; Hahn, D.; Ertl, G. Contributions of 31P-magnetic resonance spectroscopy to the understanding of dilated heart muscle disease. Eur. Heart J. 1995, 16, 115-118. [CrossRef]

177. Neubauer, S.; Horn, M.; Cramer, M.; Harre, K.; Newell, J.B.; Peters, W.; Pabst, T.; Ertl, G.; Hahn, D.; Ingwall, J.S.; et al. Myocardial Phosphocreatine-to-ATP Ratio Is a Predictor of Mortality in Patients with Dilated Cardiomyopathy. Circulation 1997, 96, 2190-2196. [CrossRef] [PubMed]

178. Horn, M.; Remkes, H.; Dienesch, C.; Hu, K.; Ertl, G.; Neubauer, S. Chronic high-dose creatine feeding does not attenuate left ventricular remodeling in rat hearts post-myocardial infarction. Cardiovasc. Res. 1999, 43, 117-124. [CrossRef]

179. McClung, J.; Hand, G.; Davis, J.; Carson, J. Effect of creatine supplementation on cardiac muscle of exercise-stressed rats. Eur. J. Appl. Physiol. 2003, 89, 26-33. [CrossRef] [PubMed]

180. Bo, H.; Jiang, N.; Ma, G.; Qu, J.; Zhang, G.; Cao, D.; Wen, L.; Liu, S.; Ji, L.L.; Zhang, Y. Regulation of mitochondrial uncoupling respiration during exercise in rat heart: Role of reactive oxygen species (ROS) and uncoupling protein 2. Free Radic. Biol. Med. 2008, 44, 1373-1381. [CrossRef]

181. Cao, F.; Zervou, S.; Lygate, C.A. The creatine kinase system as a therapeutic target for myocardial ischaemia-reperfusion injury Biochem. Soc. Trans. 2018, 46, 1119-1127. [CrossRef] [PubMed]

182. Hultman, J.; Ronquist, G.; Forsberg, J.O.; Hansson, H.E. Myocardial energy restoration of ischemic damage by administration of phosphoenolpyruvate during reperfusion. A study in a paracorporeal rat heart model. Eur. Surg. Res. 1983, 15, 200-207. [CrossRef] [PubMed]

183. Osbakken, M.; Ito, K.; Zhang, D.; Ponomarenko, I.; Ivanics, T.; Jahngen, E.G.; Cohn, M. Creatine and cyclocreatine effects on ischemic myocardium: 31P nuclear magnetic resonance evaluation of intact heart. Cardiology 1992, 80, 184-195. [CrossRef]

184. Sharov, V.G.; Saks, V.A.; Kupriyanov, V.V.; Lakomkin, V.L.; Kapelko, V.I.; Steinschneider, A.Y.; Javadov, S.A. Protection of ischemic myocardium by exogenous phosphocreatine. I. Morphologic and phosphorus 31-nuclear magnetic resonance studies. J. Thorac. Cardiovasc. Surg. 1987, 94, 749-761. [CrossRef]

185. Balestrino, M.; Sarocchi, M.; Adriano, E.; Spallarossa, P. Potential of creatine or phosphocreatine supplementation in cerebrovascular disease and in ischemic heart disease. Amino Acids 2016, 48, 1955-1967. [CrossRef]

186. ten Hove, M.; Lygate, C.A.; Fischer, A.; Schneider, J.E.; Sang, A.E.; Hulbert, K.; Sebag-Montefiore, L.; Watkins, H.; Clarke, K.; Isbrandt, D.; et al. Reduced Inotropic Reserve and Increased Susceptibility to Cardiac Ischemia/Reperfusion Injury in Phosphocreatine-Deficient Guanidinoacetate-N-Methyltransferase-Knockout Mice. Circulation 2005, 111, 2477-2485. [CrossRef]

187. Elgebaly, S.A.; Wei, Z.; Tyles, E.; Elkerm, A.F.; Houser, S.L.; Gillies, C.; Kaddurah-Daouk, R. Enhancement of the recovery of rat hearts after prolonged cold storage by cyclocreatine phosphate. Transplantation 1994, 57, 803-806. [CrossRef] [PubMed]

188. Cisowski, M.; Bochenek, A.; Kucewicz, E.; Wnuk-Wojnar, A.M.; Morawski, W.; Skalski, J.; Grzybek, H. The use of exogenous creatine phosphate for myocardial protection in patients undergoing coronary artery bypass surgery. J. Cardiovasc. Surg. 1996, 37, 75-80.

189. Ruda, M.Y.; Samarenko, M.B.; Afonskaya, N.I.; Saks, V.A. Reduction of ventricular arrhythmias by phosphocreatine (Neoton) in patients with acute myocardial infarction. Am. Heart J. 1988, 116, 393-397. [CrossRef]

190. Elgebaly, S.A.; Poston, R.; Todd, R.; Helmy, T.; Almaghraby, A.M.; Elbayoumi, T.; Kreutzer, D.L. Cyclocreatine protects against ischemic injury and enhances cardiac recovery during early reperfusion. Expert Rev. Cardiovasc. Ther. 2019, 17, 683-697. [CrossRef]

191. Roberts, J.J.; Walker, J.B. Feeding a creatine analogue delays ATP depletion and onset of rigor in ischemic heart. Am. J. Physiol. Heart Circ. Physiol. 1982, 243, H911-H916. [CrossRef]

192. Chida, K.; Otani, H.; Kohzuki, M.; Saito, H.; Kagaya, Y.; Takai, Y.; Takahashi, S.; Yamada, S.; Zuguchi, M. The Relationship between Plasma BNP Level and the Myocardial Phosphocreatine/Adenosine Triphosphate Ratio Determined by Phosphorus-31 Magnetic Resonance Spectroscopy in Patients with Dilated Cardiomyopathy. Cardiology 2006, 106, 132-136. [CrossRef]

193. Russo, E.; Nguyen, H.; Lippert, T.; Tuazon, J.; Borlongan, C.V.; Napoli, E. Mitochondrial targeting as a novel therapy for stroke. Brain Circ. 2018, 4, 84-94. [CrossRef]

194. Soustiel, J.F.; Zaaroor, M. Mitochondrial targeting for development of novel drug strategies in brain injury. Cent. Nerv. Syst. Agents Med. Chem. 2012, 12, 131-145. [CrossRef]

195. Niizuma, K.; Endo, H.; Chan, P.H. Oxidative stress and mitochondrial dysfunction as determinants of ischemic neuronal death and survival. J. Neurochem. 2009, 109, 133-138. [CrossRef]

196. Niizuma, K.; Yoshioka, H.; Chen, H.; Kim, G.S.; Jung, J.E.; Katsu, M.; Okami, N.; Chan, P.H. Mitochondrial and apoptotic neuronal death signaling pathways in cerebral ischemia. Biochim. Biophys. Acta (BBA) Mol. Basis Dis. 2010, 1802, 92-99. [CrossRef]

197. Lin, M.T.; Beal, M.F. Mitochondrial dysfunction and oxidative stress in neurodegenerative diseases. Nature 2006, 443, 787-795. [CrossRef] [PubMed]

198. He, Z.; Ning, N.; Zhou, Q.; Khoshnam, S.E.; Farzaneh, M. Mitochondria as a therapeutic target for ischemic stroke. Free Radic. Biol. Med. 2020, 146, 45-58. [CrossRef] [PubMed]

199. Nguyen, H.; Zarriello, S.; Rajani, M.; Tuazon, J.; Napoli, E.; Borlongan, C.V. Understanding the Role of Dysfunctional and Healthy Mitochondria in Stroke Pathology and Its Treatment. Int. J. Mol. Sci. 2018, 19, 2127. [CrossRef] [PubMed] 
200. Sanderson, T.H.; Reynolds, C.A.; Kumar, R.; Przyklenk, K.; Hüttemann, M. Molecular Mechanisms of Ischemia-Reperfusion Injury in Brain: Pivotal Role of the Mitochondrial Membrane Potential in Reactive Oxygen Species Generation. Mol. Neurobiol. 2013, 47, 9-23. [CrossRef]

201. Chouchani, E.T.; Pell, V.R.; James, A.M.; Work, L.M.; Saeb-Parsy, K.; Frezza, C.; Krieg, T.; Murphy, M.P. A Unifying Mechanism for Mitochondrial Superoxide Production during Ischemia-Reperfusion Injury. Cell Metab. 2016, 23, 254-263. [CrossRef]

202. Andrabi, S.S.; Parvez, S.; Tabassum, H. Ischemic stroke and mitochondria: Mechanisms and targets. Protoplasma 2020, 257, 335-343. [CrossRef]

203. Nicholls, D.G. Mitochondrial calcium function and dysfunction in the central nervous system. Biochim. Biophys. Acta 2009, 1787, 1416-1424. [CrossRef]

204. Blennow, K.; Hardy, J.; Zetterberg, H. The neuropathology and neurobiology of traumatic brain injury. Neuron 2012, 76, 886-899. [CrossRef]

205. Turner, C.E.; Byblow, W.D.; Gant, N. Creatine supplementation enhances corticomotor excitability and cognitive performance during oxygen deprivation. J. Neurosci. 2015, 35, 1773-1780. [CrossRef]

206. Zhu, S.; Li, M.; Figueroa, B.E.; Liu, A.; Stavrovskaya, I.G.; Pasinelli, P.; Beal, M.F.; Brown, R.H.; Kristal, B.S.; Ferrante, R.J.; et al. Prophylactic creatine administration mediates neuroprotection in cerebral ischemia in mice. J. Neurosci 2004, 24, 5909-5912. [CrossRef]

207. Hausmann, O.N.; Fouad, K.; Wallimann, T.; Schwab, M.E. Protective effects of oral creatine supplementation on spinal cord injury in rats. Spin. Cord 2002, 40, 449-456. [CrossRef] [PubMed]

208. Sullivan, P.G.; Geiger, J.D.; Mattson, M.P.; Scheff, S.W. Dietary supplement creatine protects against traumatic brain injury. Ann. Neurol. 2000, 48, 723-729. [CrossRef]

209. Prass, K.; Royl, G.; Lindauer, U.; Freyer, D.; Megow, D.; Dirnagl, U.; Stöckler-Ipsiroglu, G.; Wallimann, T.; Priller, J. Improved reperfusion and neuroprotection by creatine in a mouse model of stroke. J. Cereb. Blood Flow Metab. 2007, 27, 452-459. [CrossRef] [PubMed]

210. Freire Royes, L.F.; Cassol, G. The Effects of Creatine Supplementation and Physical Exercise on Traumatic Brain Injury. Mini Rev. Med. Chem. 2016, 16, 29-39. [CrossRef] [PubMed]

211. Novelli, A.; Reilly, J.A.; Lysko, P.G.; Henneberry, R.C. Glutamate becomes neurotoxic via the N-methyl-d-aspartate receptor when intracellular energy levels are reduced. Brain Res. 1988, 451, 205-212. [CrossRef]

212. Tsuji, K.; Nakamura, Y.; Ogata, T.; Shibata, T.; Kataoka, K. Rapid decrease in ATP content without recovery phase during glutamate-induced cell death in cultured spinal neurons. Brain Res. 1994, 662, 289-292. [CrossRef]

213. Carter, A.J.; Müller, R.E.; Pschorn, U.; Stransky, W. Preincubation with Creatine Enhances Levels of Creatine Phosphate and Prevents Anoxic Damage in Rat Hippocampal Slices. J. Neurochem. 1995, 64, 2691-2699. [CrossRef]

214. Brustovetsky, N.; Brustovetsky, T.; Dubinsky, J.M. On the mechanisms of neuroprotection by creatine and phosphocreatine. J. Neurochem. 2001, 76, 425-434. [CrossRef]

215. Harman, D. The aging process. Proc. Natl. Acad. Sci. USA 1981, 78, 7124-7128. [CrossRef]

216. Grimm, A.; Friedland, K.; Eckert, A. Mitochondrial dysfunction: The missing link between aging and sporadic Alzheimer's disease. Biogerontology 2016, 17, 281-296. [CrossRef]

217. Leuner, K.; Hauptmann, S.; Abdel-Kader, R.; Scherping, I.; Keil, U.; Strosznajder, J.B.; Eckert, A.; Müller, W.E. Mitochondrial dysfunction: The first domino in brain aging and Alzheimer's disease? Antiox. Redox Signal. 2007, 9, 1659-1675. [CrossRef] [PubMed]

218. Bishop, N.A.; Lu, T.; Yankner, B.A. Neural mechanisms of ageing and cognitive decline. Nature 2010, 464, 529-535. [CrossRef] [PubMed]

219. Grimm, A.; Eckert, A. Brain aging and neurodegeneration: From a mitochondrial point of view. J. Neurochem. 2017, 143, 418-431. [CrossRef] [PubMed]

220. Geary, D.C. Mitochondrial Functioning and the Relations among Health, Cognition, and Aging: Where Cell Biology Meets Cognitive Science. Int. J. Mol. Sci. 2021, 22, 3562. [CrossRef] [PubMed]

221. González-Reyes, R.E.; Aliev, G.; Ávila-Rodrigues, M.; Barreto, G.E. Alterations in Glucose Metabolism on Cognition: A Possible Link Between Diabetes and Dementia. Curr. Pharm. Des. 2016, 22, 812-818. [CrossRef] [PubMed]

222. Shieh, J.C.-C.; Huang, P.-T.; Lin, Y.-F. Alzheimer's Disease and Diabetes: Insulin Signaling as the Bridge Linking Two Pathologies Mol. Neurobiol. 2020, 57, 1966-1977. [CrossRef] [PubMed]

223. Cao, Y.; Yan, Z.; Zhou, T.; Wang, G. SIRT1 Regulates Cognitive Performance and Ability of Learning and Memory in Diabetic and Nondiabetic Models. J. Diabetes. Res. 2017, 2017, 7121827. [CrossRef]

224. Jo, D.; Kim, B.C.; Cho, K.A.; Song, J. The Cerebral Effect of Ammonia in Brain Aging: Blood-Brain Barrier Breakdown, Mitochondrial Dysfunction, and Neuroinflammation. J. Clin. Med. 2021, 10, 2773. [CrossRef]

225. Bustamante, J.; Czerniczyniec, A.; Lores-Arnaiz, S. Brain nitric oxide synthases and mitochondrial function. Front. Biosci. 2007, 12, 1034-1040. [CrossRef]

226. Felipo, V.; Butterworth, R.F. Mitochondrial dysfunction in acute hyperammonemia. Neurochem. Int. 2002, 40, 487-491. [CrossRef]

227. De la Monte, S.M.; Wands, J.R. Alzheimer's Disease is Type 3 Diabetes-Evidence Reviewed. J. Diabetes Sci. Technol. 2008, 2, 1101-1113. [CrossRef] [PubMed] 
228. Sripetchwandee, J.; Chattipakorn, N.; Chattipakorn, S.C. Links Between Obesity-Induced Brain Insulin Resistance, Brain Mitochondrial Dysfunction, and Dementia. Front. Endocrinol. 2018, 9, 496. [CrossRef] [PubMed]

229. Müller, W.E.; Eckert, A.; Kurz, C.; Eckert, G.P.; Leuner, K. Mitochondrial dysfunction: Common final pathway in brain aging and Alzheimer's disease-Therapeutic aspects. Mol. Neurobiol. 2010, 41, 159-171. [CrossRef]

230. Kaliszewska, A.; Allison, J.; Martini, M.; Arias, N. The Interaction of Diet and Mitochondrial Dysfunction in Aging and Cognition. Int. J. Mol. Sci. 2021, 22, 3574. [CrossRef] [PubMed]

231. Francis, H.M.; Stevenson, R.J. Potential for diet to prevent and remediate cognitive deficits in neurological disorders. Nutr. Rev. 2018, 76, 204-217. [CrossRef] [PubMed]

232. Head, E. Oxidative damage and cognitive dysfunction: Antioxidant treatments to promote healthy brain aging. Neurochem. Res. 2009, 34, 670-678. [CrossRef]

233. Poddar, J.; Pradhan, M.; Ganguly, G.; Chakrabarti, S. Biochemical deficits and cognitive decline in brain aging: Intervention by dietary supplements. J. Chem. Neuroanat. 2019, 95, 70-80. [CrossRef]

234. Hammett, S.T.; Wall, M.B.; Edwards, T.C.; Smith, A.T. Dietary supplementation of creatine monohydrate reduces the human fMRI BOLD signal. Neurosci. Lett. 2010, 479, 201-205. [CrossRef]

235. Watanabe, A.; Kato, N.; Kato, T. Effects of creatine on mental fatigue and cerebral hemoglobin oxygenation. Neurosci. Res. 2002, 42, 279-285. [CrossRef]

236. McMorris, T.; Harris, R.C.; Howard, A.N.; Langridge, G.; Hall, B.; Corbett, J.; Dicks, M.; Hodgson, C. Creatine supplementation, sleep deprivation, cortisol, melatonin and behavior. Physiol. Behav. 2007, 90, 21-28. [CrossRef]

237. Dworak, M.; Kim, T.; McCarley, R.W.; Basheer, R. Creatine supplementation reduces sleep need and homeostatic sleep pressure in rats. J. Sleep Res. 2017, 26, 377-385. [CrossRef] [PubMed]

238. Gibson, G.E.; Starkov, A.; Blass, J.P.; Ratan, R.R.; Beal, M.F. Cause and consequence: Mitochondrial dysfunction initiates and propagates neuronal dysfunction, neuronal death and behavioral abnormalities in age-associated neurodegenerative diseases. Biochim. Biophys. Acta 2010, 1802, 122-134. [CrossRef] [PubMed]

239. Valenti, D.; De Bari, L.; De Filippis, B.; Henrion-Caude, A.; Vacca, R.A. Mitochondrial dysfunction as a central actor in intellectual disability-related diseases: An overview of Down syndrome, autism, Fragile X and Rett syndrome. Neurosci. Biobehav. Rev. 2014, 46, 202-217. [CrossRef] [PubMed]

240. Adhihetty, P.J.; Beal, M.F. Creatine and its potential therapeutic value for targeting cellular energy impairment in neurodegenerative diseases. Neuromol. Med. 2008, 10, 275-290. [CrossRef]

241. Kley, R.A.; Tarnopolsky, M.A.; Vorgerd, M. Creatine for treating muscle disorders. Cochrane Database Syst. Rev. 2013, 2013, CD004760. [CrossRef]

242. Shao, A.; Lin, D.; Wang, L.; Tu, S.; Lenahan, C.; Zhang, J. Oxidative Stress at the Crossroads of Aging, Stroke and Depression. Aging Dis. 2020, 11, 1537-1566. [CrossRef]

243. Martin, E.I.; Ressler, K.J.; Binder, E.; Nemeroff, C.B. The Neurobiology of Anxiety Disorders: Brain Imaging, Genetics, and Psychoneuroendocrinology. Psychiatr. Clin. 2009, 32, 549-575. [CrossRef]

244. Yildiz-Yesiloglu, A.; Ankerst, D.P. Review of $1 \mathrm{H}$ magnetic resonance spectroscopy findings in major depressive disorder: A meta-analysis. Psychiatry Res. Neuroimag. 2006, 147, 1-25. [CrossRef]

245. Scaglia, F. The role of mitochondrial dysfunction in psychiatric disease. Dev. Disabil. Res. Rev. 2010, 16, 136-143. [CrossRef]

246. Agren, H.; Niklasson, F. Creatinine and creatine in CSF: Indices of brain energy metabolism in depression. Short note. J. Neural. Transm. 1988, 74, 55-59. [CrossRef]

247. Mirza, Y.; O’Neill, J.; Smith, E.A.; Russell, A.; Smith, J.M.; Banerjee, S.P.; Bhandari, R.; Boyd, C.; Rose, M.; Ivey, J.; et al. Increased medial thalamic creatine-phosphocreatine found by proton magnetic resonance spectroscopy in children with obsessivecompulsive disorder versus major depression and healthy controls. J. Child Neurol. 2006, 21, 106-111. [CrossRef] [PubMed]

248. Wood, E.; Hall, K.H.; Tate, W. Role of mitochondria, oxidative stress and the response to antioxidants in myalgic encephalomyelitis/chronic fatigue syndrome: A possible approach to SARS-CoV-2 "long-haulers"? Chronic Dis. Transl. Med. 2021, 7, 14-26. [CrossRef] [PubMed]

249. Frye, M.A.; Watzl, J.; Banakar, S.; O’Neill, J.; Mintz, J.; Davanzo, P.; Fischer, J.; Chirichigno, J.W.; Ventura, J.; Elman, S.; et al. Increased anterior cingulate/medial prefrontal cortical glutamate and creatine in bipolar depression. Neuropsychopharmacology 2007, 32, 2490-2499. [CrossRef] [PubMed]

250. Kondo, D.G.; Sung, Y.-H.; Hellem, T.L.; Fiedler, K.K.; Shi, X.; Jeong, E.-K.; Renshaw, P.F. Open-label adjunctive creatine for female adolescents with SSRI-resistant major depressive disorder: A 31-phosphorus magnetic resonance spectroscopy study. J. Affect. Disord. 2011, 135, 354-361. [CrossRef]

251. Roitman, S.; Green, T.; Osher, Y.; Karni, N.; Levine, J. Creatine monohydrate in resistant depression: A preliminary study. Bipolar Disord. 2007, 9, 754-758. [CrossRef]

252. Toniolo, R.A.; Silva, M.; Fernandes, F.d.B.F.; Amaral, J.A.d.M.S.; Dias, R.d.S.; Lafer, B. A randomized, double-blind, placebocontrolled, proof-of-concept trial of creatine monohydrate as adjunctive treatment for bipolar depression. J. Neural. Transm. 2018, 125, 247-257. [CrossRef]

253. Kious, B.M.; Kondo, D.G.; Renshaw, P.F. Creatine for the Treatment of Depression. Biomolecules 2019, 9, 406. [CrossRef]

254. Pazini, F.L.; Cunha, M.P.; Rodrigues, A.L.S. The possible beneficial effects of creatine for the management of depression. Prog. Neuropsychopharmacol. Biol. Psychiatry 2019, 89, 193-206. [CrossRef] 
255. Kondo, D.G.; Forrest, L.N.; Shi, X.; Sung, Y.-H.; Hellem, T.L.; Huber, R.S.; Renshaw, P.F. Creatine target engagement with brain bioenergetics: A dose-ranging phosphorus-31 magnetic resonance spectroscopy study of adolescent females with SSRI-resistant depression. Amino Acids 2016, 48, 1941-1954. [CrossRef]

256. D'Anci, K.E.; Allen, P.J.; Kanarek, R.B. A potential role for creatine in drug abuse? Mol. Neurobiol. 2011, 44, 136-141. [CrossRef]

257. Amital, D.; Vishne, T.; Roitman, S.; Kotler, M.; Levine, J. Open Study of Creatine Monohydrate in Treatment-Resistant Posttraumatic Stress Disorder. J. Clin. Psychiatry 2006, 67, 836-837. [CrossRef] [PubMed]

258. Allen, P.J. Creatine metabolism and psychiatric disorders: Does creatine supplementation have therapeutic value? Neurosci. Biobehav. Rev. 2012, 36, 1442-1462. [CrossRef] [PubMed]

259. Rosenthal, T.C.; Majeroni, B.A.; Pretorius, R.; Malik, K. Fatigue: An overview. Am. Fam. Physician 2008, 78, 1173-1179.

260. Jamal, G.A.; Hansen, S. Post-Viral Fatigue Syndrome: Evidence for Underlying Organic Disturbance in the Muscle Fibre. Eur. Neurol. 1989, 29, 273-276. [CrossRef] [PubMed]

261. Edwards, R.H.T.; Newham, D.J.; Peters, T.J. Muscle biochemistry and pathophysiology in postviral fatigue syndrome. Br. Med. Bull. 1991, 47, 826-837. [CrossRef] [PubMed]

262. Lane, R.J.M.; Barrett, M.C.; Taylor, D.J.; Kemp, G.J.; Lodi, R. Heterogeneity in chronic fatigue syndrome: Evidence from magnetic resonance spectroscopy of muscle. Neuromuscul. Disord. 1998, 8, 204-209. [CrossRef]

263. Behan, W.M.H.; More, I.A.R.; Behan, P.O. Mitochondrial abnormalities in the postviral fatigue syndrome. Acta Neuropathol. 1991, 83, 61-65. [CrossRef]

264. Zhang, C.; Baumer, A.; Mackay, I.R.; Linnane, A.W.; Nagley, P. Unusual pattern of mitochondrial DNA deletions in skeletal muscle of an adult human with chronic fatigue syndrome. Hum. Mol. Genet. 1995, 4, 751-754. [CrossRef]

265. Filler, K.; Lyon, D.; Bennett, J.; McCain, N.; Elswick, R.; Lukkahatai, N.; Saligan, L.N. Association of mitochondrial dysfunction and fatigue: A review of the literature. BBA Clin. 2014, 1, 12-23. [CrossRef]

266. Morris, G.; Maes, M. Mitochondrial dysfunctions in Myalgic Encephalomyelitis/chronic fatigue syndrome explained by activated immuno-inflammatory, oxidative and nitrosative stress pathways. Metab. Brain Dis. 2014, 29, 19-36. [CrossRef]

267. Malatji, B.G.; Meyer, H.; Mason, S.; Engelke, U.F.H.; Wevers, R.A.; Van Reenen, M.; Reinecke, C.J. A diagnostic biomarker profile for fibromyalgia syndrome based on an NMR metabolomics study of selected patients and controls. BMC Neurol. 2017, 17, 88 [CrossRef] [PubMed]

268. Derakhshan, M. Viral infection, a suggestive hypothesis for aetiology of chronic fatigue syndrome. J. Med. Hypotheses Ideas 2008, 2, 10-11.

269. Smith, A.P. Post-viral Fatigue: Implications for Long Covid. Asian J. Res. Infect. Dis. 2021, 17-23. [CrossRef]

270. Carfi, A.; Bernabei, R.; Landi, F. Persistent Symptoms in Patients After Acute COVID-19. JAMA 2020, 324, 603-605. [CrossRef]

271. Doykov, I.; Hällqvist, J.; Gilmour, K.C.; Grandjean, L.; Mills, K.; Heywood, W.E. 'The long tail of Covid-19'-The detection of a prolonged inflammatory response after a SARS-CoV-2 infection in asymptomatic and mildly affected patients. F1000Research 2021, 9, 1349. [CrossRef]

272. Poenaru, S.; Abdallah, S.J.; Corrales-Medina, V.; Cowan, J. COVID-19 and post-infectious myalgic encephalomyelitis/chronic fatigue syndrome: A narrative review. Ther. Adv. Infect. 2021, 8, 20499361211009385. [CrossRef]

273. Ostojic, S.M.; Stojanovic, M.; Drid, P.; Hoffman, J.R.; Sekulic, D.; Zenic, N. Supplementation with Guanidinoacetic Acid in Women with Chronic Fatigue Syndrome. Nutrients 2016, 8, 72. [CrossRef]

274. Ostojic, S.M. Diagnostic and Pharmacological Potency of Creatine in Post-Viral Fatigue Syndrome. Nutrients 2021, $13,503$. [CrossRef] 